\title{
Export fluxes in a naturally iron-fertilized area of the Southern Ocean - Part 2: Importance of diatom resting spores and faecal pellets for export
}

\author{
M. Rembauville ${ }^{1,2}$, S. Blain ${ }^{1,2}$, L. Armand ${ }^{3}$, B. Quéguiner ${ }^{4}$, and I. Salter ${ }^{1,2,5}$ \\ ${ }^{1}$ Sorbonne Universités, UPMC Univ Paris 06, UMR7621, LOMIC, Observatoire Océanologique, Banyuls-sur-Mer, France \\ ${ }^{2}$ CNRS, UMR7621, LOMIC, Observatoire Océanologique, Banyuls-sur-Mer, France \\ ${ }^{3}$ Department of Biological Sciences and Climate Futures, Macquarie University, New South Wales, Australia \\ ${ }^{4}$ Aix-Marseille Université, Université de Toulon, CNRS/INSU, IRD, MOI, UM110, Marseille, France \\ ${ }^{5}$ Alfred Wegener Institute for Polar and Marine Research, Bremerhaven, Germany
}

Correspondence to: M. Rembauville (rembauville@obs-banyuls.fr)

Received: 7 November 2014 - Published in Biogeosciences Discuss.: 10 December 2014

Revised: 27 April 2015 - Accepted: 4 May 2015 - Published: 2 June 2015

\begin{abstract}
The biological composition of the material exported to a moored sediment trap located under the winter mixed layer of the naturally fertilized Kerguelen Plateau in the Southern Ocean was studied over an annual cycle. Despite iron availability in spring, the annual particulate organic carbon (POC) export $\left(98.2 \mathrm{mmol} \mathrm{m}^{-2}\right)$ at $289 \mathrm{~m}$ was low, but annual biogenic silica export was significant $\left(114 \mathrm{mmol} \mathrm{m}^{-2}\right)$. This feature was related to the abundance of empty diatom cells and the ratio of full to empty cells exerted a first-order control in BSi : POC export stoichiometry of the biological pump. Chaetoceros Hyalochaete spp. and Thalassiosira antarctica resting spores were responsible for more than $60 \%$ of the annual POC flux that occurred during two very short export events of $<14$ days in spring-summer. Relatively low diatom fluxes were observed over the remainder of the year. Faecal pellet contribution to annual carbon flux was lower (34\%) and reached its seasonal maximum in autumn and winter $(>80 \%)$. The seasonal progression of faecal pellet types revealed a clear transition from small spherical shapes (small copepods) in spring, to larger cylindrical and ellipsoid shapes in summer (euphausiids and large copepods) and finally to large tabular shapes (salps) in autumn and winter. We propose in this high-biomass, low-export (HBLE) environment that small but highly silicified and fastsinking resting spores are able to bypass the intense grazing pressure and efficient carbon transfer to higher trophic levels that are responsible for the low fluxes observed the dur-
\end{abstract}

ing the remainder of the year. More generally our study also provides a statistical framework linking the ecological succession of diatom and zooplankton communities to the seasonality of carbon and silicon export within an iron-fertilized bloom region in the Southern Ocean.

\section{Introduction}

The Southern Ocean is the place of exposure of old upwelled waters to the atmosphere and the formation of mode waters, thereby ventilating an important part of the global ocean and playing a central role in distributing heat, carbon and nutrients in the global ocean (Sarmiento et al., 2004; Takahashi et al., 2012; Sallée et al., 2012). Silicon trapping occurs in the Southern Ocean because silicon is stripped out of the euphotic zone more efficiently than phosphorus and nitrogen (Holzer et al., 2014). It is generally acknowledged that regional variations in plankton community structure are responsible for variations in nutrient stoichiometry in the Southern Ocean (Jin et al., 2006; Weber and Deutsch, 2010) and that the biological pump is a central process regulating this stoichiometry (Ragueneau et al., 2006; Salter et al., 2012; Primeau et al., 2013). These characteristics emphasize the importance of biological processes in the Southern Ocean waters for the availability of silicic acid and nitrate (Sarmiento et al., 2004; Dutkiewicz et al., 2005) as well as 
phosphate (Primeau et al., 2013) at lower latitudes, thereby regulating part of the productivity of the global ocean. It has been proposed that change in the uptake ratio of silicate and nitrate by Southern Ocean phytoplankton in response to increased iron availability during the Last Glacial Maximum could have played a substantial role in varying atmospheric $\mathrm{CO}_{2}$ (Brzezinski et al., 2002; Matsumoto et al., 2002).

Primary production in the Southern Ocean is regulated by macro- and micronutrient availability (Martin et al., 1990; J. K. Moore et al., 2001; Nelson et al., 2001; C. M. Moore et al., 2013) and light levels as modulated by insolation and surface layer mixing (Venables and Moore, 2010; Blain et al., 2013). The complex interaction of these factors introduces strong spatial heterogeneity in the distribution of primary producer biomass (Arrigo et al., 1998; Thomalla et al., 2011). In particular, high-nutrient, low-chlorophyll (HNLC) areas in the open ocean contrast strongly with highly productive, naturally fertilized blooms located downstream of island systems such as the Kerguelen Plateau (Blain et al., 2001, 2007), Crozet Islands (Pollard et al., 2002) and South Georgia (Park et al., 2010; Tarling et al., 2012). The diatomdominated phytoplankton blooms characteristic of these island systems are the product of multiple environmental conditions favourable for their rapid growth (Quéguiner, 2013), which appear to promote POC export from the mixed layer (Nelson et al., 1995; Buesseler, 1998). However the ecological traits of certain species can impact the BSi : POC export stoichiometry (Crawford, 1995; Salter et al., 2012), and may therefore control the biogeochemical function of a particular region of the Southern Ocean (Smetacek et al., 2004; Assmy et al., 2013).

Among the numerous ecological characteristics of plankton communities, algal aggregation (Jackson et al., 2005; Burd and Jackson, 2009), mesozooplankton faecal pellets (Lampitt et al., 1990; Wilson et al., 2008, 2013), vertical migrations of zooplankton (Jackson and Burd, 2001; Steinberg et al., 2002; Davison et al., 2013), radiolarian faecal pellets (Lampitt et al., 2009) and diatom resting spore formation (Salter et al., 2012; Rynearson et al., 2013) have all been highlighted as efficient vectors of carbon export out of the surface mixed layer. The challenge in describing the principal ecological processes regulating POC export fluxes is the requirement to have direct access to sinking particles. Many of the processes described occur in the upper layers of the ocean, where circulation can strongly influence the reliability of sediment trap collections (Baker et al., 1988; Buesseler et al., 2007). Short-term deployments of free-drifting sediment traps can be an efficient solution to minimize the hydrodynamic bias (Buesseler et al., 2000; Lampitt et al., 2008), but spatial and temporal decoupling of production and export needs to be considered (Salter et al., 2007; Rynearson et al., 2013). In regions characterized by relatively weak circulation, moored sediment trap observations in areas of naturally fertilized production can track temporal succession of exported material from long-term (several-month) blooms (Westberry et al., 2013). Such an approach can partially resolve how ecological processes in plankton communities regulate $\mathrm{POC}$ and biomineral export out of the mixed layer (Salter et al., 2012, 2014), although selective processes during export may modify original surface features.

The central Kerguelen Plateau is a good environment to study the ecological vectors of export with sediment traps due to the naturally fertilized recurrent bloom (Blain et al., 2007) and shallow bathymetry that breaks the strong Antarctic Circumpolar Current flow (Park et al., 2008, 2014). As reported in the companion paper (Rembauville et al., 2015), annual POC export measured by the sediment trap deployment at $289 \mathrm{~m}$ beneath the southeastern iron-fertilized Kerguelen bloom was $98 \pm 4 \mathrm{mmol} \mathrm{m}^{-2} \mathrm{yr}^{-1}$. This downward flux of carbon may account for as little as $\sim 1.5 \%$ of seasonal net community carbon production $\left(6.6 \pm 2.2 \mathrm{~mol} \mathrm{~m}^{-2}\right.$; Jouandet et al., 2008) and <2\% of seasonally integrated POC export estimated at $200 \mathrm{~m}$ from a dissolved inorganic carbon budget (5.1 $\mathrm{mol} \mathrm{C} \mathrm{m}^{-2}$; Blain et al., 2007). Although hydrodynamical and biological biases related to the shallow moored sediment trap deployment may partly explain the low POC fluxes we report, independent measurements of low POC fluxes $(>300 \mathrm{~m})$ at the same station (Ebersbach and Trull, 2008; Jouandet et al., 2014) are consistent with the hypothesis of flux attenuation below the winter mixed layer. These observations suggest a "high-biomass, low-export" (HBLE; Lam and Bishop, 2007) status characterizing the productive Kerguelen Plateau. HBLE status appears to be a common feature of other productive sites of the Southern Ocean (Lam and Bishop, 2007; Ebersbach et al., 2011; Lam et al., 2011; Maiti et al., 2013; Cavan et al., 2015). Describing the temporal succession of POC and BSi flux vectors from the Kerguelen Plateau is of interest to increase our understanding of the ecological processes characterizing HBLE environments.

Numerous studies have described diatom fluxes from sediment trap records in the Southern Ocean (Leventer and Dunbar, 1987; Fischer et al., 1988, 2002; Abelmann and Gersonde, 1991; Leventer, 1991; Gersonde and Zielinski, 2000; Pilskaln et al., 2004; Ichinomiya et al., 2008; Salter et al., 2012). Highest diatom fluxes recorded by sediment traps (> $10^{9}$ valves $\mathrm{m}^{-2} \mathrm{~d}^{-1}$ ) were observed in the seasonal ice zone (SIZ) near Prydz Bay and Adélie Land and were dominated by Fragilariopsis kerguelensis and smaller Fragilariopsis species such as Fragilariopsis curta and Fragilariopsis cylindrus (Suzuki et al., 2001; Pilskaln et al., 2004). These high fluxes occurred in summer and were associated with the melting of sea ice. Changes in light availability and melt water input appear to establish favourable conditions for the production and export of phytoplankton cells (Romero and Armand, 2010). In the Permanently Open Ocean Zone (POOZ), highest diatom fluxes recorded were 2 orders of magnitude lower, $\sim 10^{7}$ valves $\mathrm{m}^{-2} \mathrm{~d}^{-1}$ (Abelmann and Gersonde, 1991; Salter et al., 2012; Grigorov et al., 2014), and typically represented by F. kerguelensis and Thalassionema nitzschioides. One notable exception is the naturally iron- 
fertilized waters downstream of the Crozet Plateau, where resting spores of Eucampia antarctica var. antarctica dominated the diatom export assemblage (Salter et al., 2012).

Other studies have reported faecal pellet contribution to POC fluxes in the Southern Ocean (Dunbar, 1984; G. Wefer et al., 1988; G. G. Wefer et al., 1990; Wefer and Fisher, 1991; Dubischar and Bathmann, 2002; Suzuki et al., 2001, 2003; Accornero and Gowing, 2003; Schnack-Schiel and Isla, 2005; Gleiber et al., 2012), with a particular emphasis on shelf environments where faecal pellet contribution to POC flux was typically higher than in the oceanic regions (Wefer et al., 1990; Wefer and Fischer, 1991; Schnack-Schiel and Isla, 2005). In the Ross Sea, a northward decreasing contribution to carbon flux of 59, 38 and $15 \%$ for southern, central and northern areas was reported from $235 \mathrm{~m}$ sediment traps deployments (Schnack-Schiel and Isla, 2005). Faecal pellets in the Ross Sea were generally represented by larger shapes, with only 2 to $3 \%$ of them present as small spherical or ellipsoid shapes, and total faecal pellet flux was slightly higher than $10^{3}$ pellets $\mathrm{m}^{-2} \mathrm{~d}^{-1}$. High faecal pellet contributions to carbon fluxes (>90\%) have been observed in the Bransfield Strait and the marginal ice zone of the Scotia Sea, and have been linked to the abundance of the Antarctic krill Euphausia superba, resulting in maximum recorded fluxes of $>5 \times 10^{5}$ pellets $\mathrm{m}^{-2} \mathrm{~d}^{-1}$ (von Bodungen, 1986; von Bodungen et al., 1987; Wefer et al., 1988). The strong contribution of krill faecal pellets to carbon flux in the western Antarctic Peninsula was confirmed over several years of observations, with the highest contributions to carbon flux succeeding the phytoplankton bloom in January and February (Gleiber et al., 2012).

In the present study, particulate material exported from the mixed layer in the naturally fertilized Permanently Open Ocean Zone (POOZ) of the Kerguelen Plateau is described from an annual sediment trap mooring. To develop our understanding of seasonal variability in the ecological flux vectors and particle biogeochemistry, we investigate the link between the chemical (POC, PON, BSi) and biological (diatom species and faecal pellet types) components of exported particles. Furthermore, we advance the limitations of previous studies by explicitly distinguishing between full and empty diatom cells in the exported material and thereby determine species-specific roles for carbon and silica export.

\section{Materials and methods}

As part of the multidisciplinary research programme KEOPS2, a moored sediment trap (Technicap PPS3) was deployed at $289 \mathrm{~m}$ (seafloor depth: $527 \mathrm{~m}$ ) at the representative bloom station A3 $\left(50^{\circ} 38.3^{\prime} \mathrm{S}, 72^{\circ} 02.6^{\prime} \mathrm{E}\right)$ for a period of 321 days (21 October 2011 to 7 September 2012). The sediment trap mooring was located within an iron-fertilized bloom site on the southern part of the Kerguelen Plateau (Blain et al., 2007). The cup rotation dates of the sediment trap are listed in Table 1. Details of sediment trap design, hydrological conditions, sample processing, POC and PON analyses, and surface chlorophyll $a$ data extraction are described in a companion paper (Rembauville et al., 2015). Comparison with thorium-based estimates of carbon export suggests a trapping efficiency of $15-30 \%$ relative to the proxy, although strong particle flux attenuation between $200 \mathrm{~m}$ and the trap depth $(289 \mathrm{~m})$ might also contribute to the low fluxes. We therefore interpret our results to accurately reflect the relationships between the biological and geochemical signals of the material caught by the sediment trap, which we acknowledge may not necessarily represent the entire particle export at $289 \mathrm{~m}$.

\subsection{Biogenic and lithogenic silicon analyses}

For the analysis of biogenic silica (BSi) and lithogenic silica (LSi), 2 to $8 \mathrm{mg}$ of freeze-dried material was weighed (Sartorius precision balance, precision $10^{-4} \mathrm{~g}$ ) and placed into Falcon tubes. The extraction of silicon from biogenic and lithogenic particle phases was performed following the Ragueneau et al. (2005) triple NaOH/HF extraction procedure. Silicic acid $\left(\mathrm{Si}(\mathrm{OH})_{4}\right)$ resulting from $\mathrm{NaOH}$ extractions was measured automatically on a Skalar 5100 autoanalyser, whereas $\mathrm{Si}(\mathrm{OH})_{4}$ resulting from HF extraction was measured manually on a Milton Roy Spectronic 401 spectrophotometer. $\mathrm{Si}(\mathrm{OH})_{4}$ analyses were performed colorimetrically following Aminot and Kerouel (2007). Standards for the analysis of samples from the HF extraction were prepared in an $\mathrm{HF} / \mathrm{H}_{3} \mathrm{BO}_{4}$ matrix, ensuring the use of an appropriate calibration factor that differs from Milli-Q water. The contribution of LSi to the first leaching was determined by using $\mathrm{Si}$ : Al ratios from a second leaching step (Ragueneau et al., 2005). Aluminium concentrations were measured by spectrophotometry (Howard et al., 1986). The triple extraction procedure is optimized for samples with a BSi content $<10 \mu$ mol. For some samples (cups \#3, \#4, \#6, \#7, \#8, \#9 and \#10) the $\mathrm{Si}: \mathrm{Al}$ molar ratio in the second leachate was high (>10), indicating the incomplete dissolution of BSi. For these samples it was not possible to use $\mathrm{Si}: \mathrm{Al}$ ratios to correct for LSi leaching. A crustal Si : Al mass ratio of 3.74 (Taylor and McClennan, 1986) was therefore used and applied to all the samples for consistency. Precision (estimated from measurement of 25 independent samples) was $13 \mathrm{nmol} \mathrm{mg}^{-1}$, which represents $<1 \%$ of the BSi content in all samples and $14 \%$ of the mean LSi content. Blank triplicates from each extraction were below the detection limit. BSi results from this method were compared to the kinetic method from DeMaster (1981). There was an excellent agreement between the two methods (Spearman rank correlation, $n=12, p<0.001, \mathrm{BSi}_{\text {kinetic }}=1.03 \mathrm{BSi}_{\text {triple extraction }}-$ 0.08; data not shown). To estimate the contribution of opal to total mass flux, we assumed an opal composition of $\mathrm{SiO}_{2} 0.4$ $\mathrm{H}_{2} \mathrm{O}$ (Mortlock and Froelich, 1989).

In order to correct for the dissolution of BSi during deployment and storage, $\mathrm{Si}(\mathrm{OH})_{4}$ excess was analysed in the over- 
Table 1. Sediment bulk flux and composition results.

\begin{tabular}{|c|c|c|c|c|c|c|c|c|c|c|c|c|}
\hline Cup & $\begin{array}{r}\text { Cup } \\
\text { opening date }\end{array}$ & $\begin{array}{r}\text { Cup } \\
\text { closing date }\end{array}$ & $\begin{array}{l}\text { Collection } \\
\text { time (days) }\end{array}$ & Season & $\begin{array}{r}\text { Mass flux } \\
\left(\mathrm{mg} \mathrm{m}^{-2} \mathrm{~d}^{-1}\right)^{*}\end{array}$ & $\begin{array}{r}\text { POC flux } \\
\left(\mathrm{mmol} \mathrm{m}^{-2} \mathrm{~d}^{-1}\right)^{*}\end{array}$ & $\begin{array}{r}\text { PON flux } \\
\left(\mathrm{mmol} \mathrm{m}^{-2} \mathrm{~d}^{-1}\right)^{*}\end{array}$ & $\begin{array}{r}\text { BSi Flux } \\
\left(\mathrm{mmol} \mathrm{m}^{-2} \mathrm{~d}^{-1}\right)\end{array}$ & $\begin{array}{r}\text { LSi flux } \\
\left(\mu \mathrm{mol} \mathrm{m}^{-2} \mathrm{~d}^{-1}\right)\end{array}$ & $\%$ opal & POC:PON & BSi : POC \\
\hline 1 & $21 / 10 / 2011$ & $04 / 11 / 2011$ & 14 & Spring & 52.2 & 0.15 & 0.02 & 0.51 & 26.6 & 65.6 & 6.80 & 3.46 \\
\hline 2 & $04 / 11 / 2011$ & $18 / 11 / 2011$ & 14 & Spring & 28.1 & 0.14 & 0.02 & 0.30 & 18.0 & 70.8 & 6.09 & 2.18 \\
\hline 3 & $18 / 11 / 2011$ & $02 / 12 / 2011$ & 14 & Spring & 54.1 & 0.15 & 0.02 & 0.51 & 13.0 & 63.9 & 7.33 & 3.43 \\
\hline 4 & $02 / 12 / 2011$ & $12 / 12 / 2011$ & 10 & Summer & 261.3 & 1.60 & 0.23 & 2.60 & 20.9 & 66.9 & 6.95 & 1.63 \\
\hline 5 & $12 / 12 / 2011$ & $22 / 12 / 2011$ & 10 & Summer & 23.1 & 0.34 & 0.05 & 0.21 & 4.4 & 62.4 & 6.87 & 0.64 \\
\hline 6 & $22 / 12 / 2011$ & $01 / 01 / 2012$ & 10 & Summer & 74.8 & 0.51 & 0.08 & 0.37 & 8.2 & 32.9 & 6.70 & 0.72 \\
\hline 7 & $01 / 01 / 2012$ & $11 / 01 / 2012$ & 10 & Summer & 80.5 & 0.42 & 0.06 & 0.55 & 8.9 & 46.0 & 6.73 & 1.32 \\
\hline 8 & $11 / 01 / 2012$ & $25 / 01 / 2012$ & 14 & Summer & 59.8 & 0.34 & 0.05 & 0.50 & 5.4 & 56.5 & 6.94 & 1.48 \\
\hline 9 & $25 / 01 / 2012$ & $08 / 02 / 2012$ & 14 & Summer & 238.7 & 1.47 & 0.20 & 2.19 & 7.2 & 61.7 & 7.38 & 1.49 \\
\hline 10 & 08/02/2012 & $22 / 02 / 2012$ & 14 & Summer & 75.8 & 0.55 & 0.08 & 0.72 & 6.1 & 64.2 & 6.97 & 1.32 \\
\hline 11 & $22 / 02 / 2012$ & $31 / 05 / 2012$ & 99 & Autumn & 24.4 & 0.27 & 0.03 & 0.08 & 1.5 & 21.5 & 8.09 & 0.29 \\
\hline 12 & $31 / 05 / 2012$ & $07 / 09 / 2012$ & 99 & Winter & 5.1 & 0.04 & 0.01 & 0.03 & 2.2 & 35.0 & 6.06 & 0.66 \\
\hline \multicolumn{3}{|c|}{ Annual export** } & 322 & & 14438 & 98.2 & 13.6 & 114 & 1.85 & 53.1 & 7.2 & 1.2 \\
\hline
\end{tabular}

* Data from Rembauville et al. (2015). ${ }^{* *}$ Values assume no flux during the unsampled portion of the year.

lying preservative solution. Particulate BSi fluxes were corrected for dissolution assuming that excess silicic acid originated only from the dissolution of BSi phases. $\mathrm{Si}(\mathrm{OH})_{4}$ excess was always $<10 \%$ of total (dissolved + particulate) $\mathrm{Si}$ concentrations. Error propagation for POC, PON, BSi fluxes and molar ratios was calculated as the quadratic sum of the relative error from triplicate measurements of each variable.

\subsection{Diatom identification, fluxes and biomass}

Many sediment trap studies reporting diatom fluxes in the Southern Ocean use a micropalaeontological protocol that oxidizes organic material $\left(\mathrm{KMnO}_{4}, \mathrm{HCl}, \mathrm{H}_{2} \mathrm{O}_{2}\right)$, thereby facilitating the observation of diatom valves (see Romero et al., 1999, 2000, for a description). In the present manuscript, our specific aim was to separately enumerate full and empty diatom cells captured by the sediment trap to identify key carbon or silicon exporters amongst the diatom species. We therefore used a biological method following a similar protocol to that of Salter et al. $(2007,2012)$. To prepare samples for counting, $2 \mathrm{~mL}$ of a gently homogenized one-eighth wet aliquot was diluted in a total volume of $20 \mathrm{~mL}$ of artificial seawater $(S=34)$. In order to minimize the exclusion and/or breaking of large or elongated diatom frustules (e.g. Thalassiothrix antarctica), the pipette tip used for sub-sampling was modified to increase the tip aperture to $>2 \mathrm{~mm}$. The diluted and homogenized sample was placed in a Sedgewick Rafter counting chamber (Pyser SGE S52, $1 \mathrm{~mL}$ chamber volume). Each sample was observed under an inverted microscope (Olympus IX71) with phase contrast at $200 \times$ and $400 \times$ magnification. Diatom enumeration and identification was made from one-quarter to one-half of the counting chamber (depending on cell abundance). The total number of diatoms counted was $>400$ in all the cups, with the exception of the winter cup \#12 (May-September 2012), where the diatom abundance was low ( $<100$ diatoms counted). Diatoms species were identified following the recommendations of Hasle and Syvertsen (1997). All whole, intact and recognizable frustules were enumerated. Full and empty cells were counted separately, following suggestions in Assmy et al. (2013).

Due to the lower magnification used and preserved cell contents sometimes obscuring taxonomic features on the valve face, taxonomic identification to the species level was occasionally difficult and necessitated the categorizing of diatom species to genus or taxa groupings in the following manner: Chaetoceros species of the subgenus Hyalochaete resting spores (CRS) were not differentiated into species or morphotypes but were counted separately from the vegetative cells; Fragilariopsis separanda and Fragilariopsis rhombica were grouped as Fragilariopsis separanda/rhombica; Membraneis imposter and Membraneis challengeri and species of the genera Banquisia and Manguinea were denominated as Membraneis spp. (Armand et al., 2008a); diatoms of the genus Haslea and Pleurosigma were grouped as Pleurosigma spp.; all Pseudo-nitzschia species encountered were grouped as Pseudo-nitzschia spp.; Rhizosolenia antennata and Rhizosolenia styliformis were grouped as Rhizosolenia antennata/styliformis; large and rare Thalassiosira oliverana and Thalassiosira tumida were grouped as Thalassiosira spp.; Thalassiosira antarctica resting spores (TRS) were identified separately from the vegetative cells; small centric diatoms $(<20 \mu \mathrm{m})$ represented by Thalassiosira gracilis and other Thalassiosira species were designated as small centrics $(<20 \mu \mathrm{m})$; and finally large and rare centrics, including Azpeitia tabularis, Coscinodiscus spp. and Actinocyclus curvatulus, were grouped as large centrics $(>20 \mu \mathrm{m})$. Full and empty frustules of each species or taxa grouping were distinguished and enumerated separately. The cell flux for each diatom species or taxa grouping was calculated according to Eq. (1):

Cell flux $=N_{\text {diat }} \cdot d \cdot 8 \cdot V_{\text {cup }} \cdot \frac{1}{0.125} \cdot \frac{1}{\text { days }} \cdot$ chamber fraction,

where Cell flux is in valves $\mathrm{m}^{-2} \mathrm{~d}^{-1}, N_{\text {diat }}$ is the number of cells enumerated for each diatom classification, $d$ is the dilution factor from the original wet aliquot, 8 is the total number of wet aliquots comprising one sample cup, $V_{\text {cup }}$ is the volume of each wet aliquot, 0.125 is the Technicap PPS $/ 3$ sedi- 
ment trap collecting area $\left(\mathrm{m}^{2}\right)$, days is the collecting period, and chamber fraction is the surface fraction of the counting chamber that was observed (one-quarter or one-half). The annually integrated full and empty diatom flux for each species was calculated as follows:

Annual flux $(x)=\sum_{i=1}^{12}\left(\operatorname{Flux}_{(x) i} \cdot\right.$ days $\left._{i}\right)$,

where Annual flux $(x)$ is the annually integrated flux of a full or empty diatom species $x\left(\operatorname{cell~m}^{-2} \mathrm{yr}^{-1}\right)$, Flux $(x) i$ is the full or empty flux of this species in the cup number $i$ (cell $\mathrm{m}^{-2} \mathrm{~d}^{-1}$ ) and days $i$ is the collecting time for the cup number $i(d)$. The calculations assume that negligible export occurred during the month of September, which was not sampled by the sediment trap. We consider this assumption reasonable based on the preceding flux profile and low concentration of satellite-derived chlorophyll $a$ (Rembauville et al., 2015).

We directly compared the micropalaeontological (as used in Rigual-Hernández et al. (2015) and biological counting techniques in our sediment trap samples and noted the loss of several species (Chaetoceros decipiens, Chaetoceros dichaeta, Corethron pennatum, Corethron inerme, Guinardia cylindrus and Rhizosolenia chunii) under the micropalaeontological technique. We attribute this to the aggressive chemical oxidation techniques used to "clean" the samples as well as the centrifugation steps, which may also selectively destroy or dissolve certain frustules. For the species that were commonly observed by both techniques, total valve flux was in good agreement (Spearman rank correlation, $n=12$, $\rho=0.91, p<0.001$; data not shown) although consistently lower with the micropalaeontolgical technique, probably due to the loss of certain frustules described above. Full details of this method comparison are in preparation for a separate submission.

Diatoms species that contributed to more than $1 \%$ of total full cell flux were converted to carbon flux. For E. antarctica var. antarctica, Fragilariopsis kerguelensis, Fragilariopsis separanda/rhombica, Pseudo-nitzschia spp. and Thalassionema nitzschioides spp., we used published cell-specific carbon content $\left(\mathrm{Cell}_{\mathrm{C}}, \mathrm{pg} \mathrm{C} \mathrm{cell}^{-1}\right.$ ) for diatoms communities of the Kerguelen Plateau from Cornet-Barthaux et al. (2007). As Chaetoceros Hyalochaete resting spores (CRS) and Thalassiosira antarctica resting spores (TRS) largely dominated the full diatom fluxes (> 80\%), an appropriate estimation of their carbon content based on the specific sizes observed in our data set was required for accurate quantification of their contribution to carbon fluxes. Biomass calculations for both CRS and TRS were determined from $>50$ randomly selected complete resting spores observed in splits from cups \#4 to \#11 (December 2011 to May 2012). Morphometric measurements (pervalvar and apical axis) were made using the Fiji image processing package (available at http: //fiji.sc/Fiji) on images taken with an Olympus DP71 cam- era. Cell volumes followed appropriate shape-designated calculations from Hillebrand et al. (1999; Table 2). The cell volume coefficient of variation was 46 and $54 \%$ for CRS and TRS, respectively. CRS carbon content was estimated from the derived cell volume using the volume-to-carbon re-

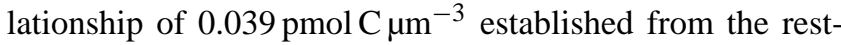
ing spore of Chaetoceros pseudocurvisetus (Kuwata et al., 1993), leading to a mean Cell $\mathrm{C}$ value of $227 \mathrm{pg} \mathrm{C}$ cell $^{-1}$ (Table 2 ). There is currently no volume-to-carbon relationship for Thalassiosira antarctica resting spores described in the literature; therefore, the allometric relationship for vegetative diatoms (Menden-Deuer and Lessard, 2000) was used to calculate our TRS carbon content, giving a mean Cell $\mathrm{C}_{\mathrm{C}}$ value of $1428 \mathrm{pg} \mathrm{C}$ cell $^{-1}$ (Table 2). Full diatom fluxes were converted to carbon fluxes as follows:

$\mathrm{C} \operatorname{flux}_{(x)}=\frac{\operatorname{Flux}_{(x)} \cdot \operatorname{Cell}_{\mathrm{C}(x)}}{M_{{ }^{12} \mathrm{C}} \cdot 10^{9}}$,

where $\mathrm{C}$ flux $(x)$ is the carbon flux carried by each diatom species $x\left(\operatorname{mmol~C~m}^{-2} \mathrm{~d}^{-1}\right)$, Flux $(x)$ is the full cell numerical flux of species $x\left(\right.$ cell m$\left.^{-2} \mathrm{~d}^{-1}\right)$, Cell $_{C(x)}$ is the carbon content of species $x$ (pg Ceell $\left.{ }^{-1}\right), M_{12 \mathrm{C}}$ is the molecular weight of ${ }^{12} \mathrm{C}\left(12 \mathrm{~g} \mathrm{~mol}^{-1}\right)$ and $10^{9}$ is a conversion factor from pmol to mmol.

\subsection{Faecal pellet composition and fluxes}

To enumerate faecal pellets, an entire one-eighth aliquot of each sample cup was placed in a gridded Petri dish and observed under a stereomicroscope (Zeiss Discovery V20) coupled to a camera (Zeiss Axiocam ERc5s) at $10 \times$ magnification. Photographic images $(2560 \times 1920$ pixels, $3.49 \mu \mathrm{m} \mathrm{pixel}^{-1}$ ) covering the entire surface of the Petri dish were acquired. Following Wilson et al. (2013), faecal pellets were classified into five types according to their shape: spherical, ovoid, cylindrical, ellipsoid and tabular. The flux of each faecal pellet class $\left(\mathrm{nb} \mathrm{m}^{-2} \mathrm{~d}^{-1}\right)$ was calculated as follows:

Faecal pellet flux $=N_{\mathrm{FP}} \cdot 8 \cdot \frac{1}{0.125} \cdot \frac{1}{\text { days }}$,

where $N_{\mathrm{FP}}$ is the number of pellets within each class observed in the one-eight aliquot. The other constants are as described in Eq. (1). Individual measurements of the major and minor axis for each faecal pellet were performed with the Fiji software. The total number of spherical, ovoid, cylindrical, ellipsoid and tabular faecal pellets measured was 4041, 2047, 1338, 54 and 29, respectively. Using these dimensions, faecal pellet volume was determined using the appropriate shape equation (e.g. sphere, ellipse, cylinder, ovoid/ellipse) and converted to carbon using a factor of $0.036 \mathrm{mg} \mathrm{C} \mathrm{mm}^{-3}$ (Gonzalez and Smetacek, 1994). Due to the irregularity of the tabular shapes preventing the use of a single equation to calculate their volume, a constant value of $119 \mu \mathrm{g} \mathrm{C}$ pellet $^{-1}$, representing a mid-range value for tabular shapes (Madin, 1982), was applied to tabular faecal pellets (Wilson et al., 
Table 2. Chaetoceros resting spores (CRS) and Thalassiosira antarctica resting spores (TRS) measurement and biomass data from station A3 sediment trap. The range and the mean value (bold) are reported for each variable.

\begin{tabular}{|c|c|c|c|c|c|c|c|c|}
\hline $\begin{array}{l}\text { Spore } \\
\text { type }\end{array}$ & $\begin{array}{r}\text { Number } \\
\text { measured }\end{array}$ & $\begin{array}{l}\text { Pervalvar } \\
\text { axis }(\mu \mathrm{m})\end{array}$ & $\begin{array}{r}\text { Apical axis } \\
(\mu \mathrm{m})\end{array}$ & Shape $^{\mathrm{a}}$ & $\begin{array}{r}\text { Cell volume } \\
\left(\mu \mathrm{m}^{3}\right)\end{array}$ & $\begin{array}{l}\text { Volume-carbon } \\
\text { relationship }\end{array}$ & $\begin{array}{l}\text { Cell carbon content } \\
\left(\mathrm{pmol} \mathrm{Cell}^{-1}\right)\end{array}$ & $\begin{array}{l}\text { Cell carbon content } \\
\left(\operatorname{pg~C~cell~}^{-1}\right)\end{array}$ \\
\hline CRS & 63 & $\begin{array}{r}3.1-8.5 \\
6\end{array}$ & $\begin{array}{r}7.2-17.4 \\
12.1\end{array}$ & $\begin{array}{r}\text { Cylinder }+ \\
\text { two cones }\end{array}$ & $\begin{array}{r}116.9-1415 \\
\mathbf{4 8 3}\end{array}$ & 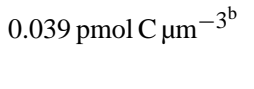 & $\begin{array}{r}5-55 \\
19\end{array}$ & $\begin{array}{r}55-662 \\
227\end{array}$ \\
\hline TRS & 57 & $\begin{array}{r}10.2-26 \\
\mathbf{2 0 . 8}\end{array}$ & $\begin{array}{r}25.6-35.3 \\
\mathbf{3 2 . 6}\end{array}$ & $\begin{array}{r}\text { Cylinder }+ \\
\text { two half-spheres }\end{array}$ & $\begin{array}{r}14035-48477 \\
\mathbf{3 5 5 0 2}\end{array}$ & $\mathrm{C}=0.582 \times V^{0.811^{\mathrm{c}}}$ & $\begin{array}{r}56-153 \\
119\end{array}$ & $\begin{array}{r}672-1839 \\
\mathbf{1 4 2 8}\end{array}$ \\
\hline
\end{tabular}

a As defined in Hillebrand et al. (1999). ${ }^{\mathrm{b}}$ Data representative of Chaetoceros pseudocurvisetus resting spore (Kuwata et al. 1993). ${ }^{\mathrm{c}}$ Equation from Menden-Deuer and

Lessard (2000), where $\mathrm{C}$ is the carbon content (pg C) and $V$ is the cell volume $\left(\mu \mathrm{m}^{3}\right)$.

2013). This value was appropriate because the observed tabular faecal pellets were within the size range reported in Madin (1982). Ranges and mean values of faecal pellet volumes and carbon content are reported in Table 3. Faecal fluff and disaggregated faecal pellets were not considered in these calculations because quantitative determination of their volume is difficult. We acknowledge that fragmentation of larger pellets may represent an artifact of the sample-splitting procedure. Alternatively, their presence may also result from natural processes within the water column, although dedicated sampling techniques (e.g. polyacrylamide gel traps) are required to make this distinction (Ebersbach et al., 2014, 2011; Ebersbach and Trull, 2008; Laurenceau-Cornec et al., 2015). Consequently our present quantification of faecal pellet carbon flux should be considered as lower-end estimates.

The precision of our calculations depends on the reliability of carbon-volume conversion factors of faecal pellets, which vary widely in the literature, as well as variability in diatom resting spore volumes (Table 2). To constrain the importance of this variability on our quantitative estimation of $\mathrm{C}$ flux, we calculated upper and lower error bounds using a constant scaling of the conversion factors $( \pm 50 \%)$.

\subsection{Statistical analyses}

Correspondence analysis was performed to summarize the seasonality of diatom export assemblages. This approach projects the original variables (here full and empty cells) onto a few principal axes that concentrate the information of the chi-squared $\left(\chi^{2}\right)$ distance between both observations and variables (Legendre and Legendre, 1998). $\chi^{2}$ distance is very sensitive to rare events. Consequently, only species with an annual mean flux higher than $10 \%$ of the mean annually integrated flux of all the species were retained in the correspondence analysis. This selection was performed separately on full and empty cell fluxes.

Partial least-squares regression (PLSR) analysis was used to examine the relationships between ecological flux vectors (full and empty diatom cells and faecal pellet fluxes as columns of the $X$ matrix, cups being the rows) and bulk geochemical properties (POC flux, PON flux, BSi flux, POC:PON and BSi:POC molar ratio and columns in the
$Y$ matrix) of the exported material. The principle of PLSR is to decompose both the $X$ and $Y$ matrix into their principal components using principal component analysis and then use these principal components to regress $Y$ in $X$ (Abdi, 2010). PLSR is capable of modelling response variables from a large set of predictors. The same filter as for the correspondence analysis (full and empty cell fluxes $>10 \%$ of the total mean flux) was applied.

\section{Results}

\subsection{Chemical composition of the settling material}

Time series of the chemical signature of the settling material are presented in Fig. 1, and export fluxes are reported in Table 1. POC and PON fluxes are also reported and discussed in the companion paper (Rembauville et al., 2015). BSi fluxes exhibited the same seasonal pattern as POC fluxes (Fig. 1c) with low fluxes $\left(<1 \mathrm{mmol} \mathrm{m}^{-2} \mathrm{~d}^{-1}\right)$ except during the two intense events $\left(2.60 \pm 0.03\right.$ and $2.19 \pm 0.10 \mathrm{mmol} \mathrm{m}^{-2} \mathrm{~d}^{-1}$, mean \pm standard deviation). LSi fluxes were highest in spring (> $10 \mu \mathrm{mol} \mathrm{m}^{-2} \mathrm{~d}^{-1}$ in cups \#1 to \#4, October to December 2011, Table 1). The contribution of LSi to total particulate Si was 5 and $10 \%$, respectively, in cups \#1 (October/November 2011) and \#12 (May to September 2012) and lower than $3 \%$ the remainder of the year. The BSi:POC molar ratio was highest at the beginning of the season (between $2.18 \pm 0.19$ and $3.46 \pm 0.16$ in the first three cups from October to December 2011, blue line in Fig. 1c) and dropped to $0.64 \pm 0.06$ in cup \#5 (end of December 2011), following the first export event. BSi : POC ratios were close in the two export events $(1.62 \pm 0.05$ and $1.49 \pm 0.08)$. The lowest BSi : POC ratio was observed in autumn in cup \#11 $(0.29 \pm 0.01$, February to May 2012). Similarly, the opal contribution to total mass flux was highest in spring $(70.8 \%$ in cup \#2, November 2011) and lowest in autumn (21.5\% in cup \#11, February to May 2012). 
Table 3. Faecal pellet measurement and biomass estimations from the station A3 sediment trap. For each variable, the range and the mean value (bold) are reported.

\begin{tabular}{|c|c|c|c|c|c|c|c|c|}
\hline $\begin{array}{l}\text { Faecal } \\
\text { pellet shape }\end{array}$ & $\begin{array}{r}\text { Number } \\
\text { measured }\end{array}$ & $\begin{array}{r}\text { Major axis } \\
(\mu \mathrm{m})(\mathrm{a})\end{array}$ & $\begin{array}{r}\text { Minor axis } \\
(\mu \mathrm{m})(\mathrm{b})\end{array}$ & $\begin{array}{l}\text { Volume } \\
\text { equation }\end{array}$ & $\begin{array}{r}\text { Volume } \\
\left(\mu \mathrm{m}^{3}\right)\end{array}$ & $\begin{array}{r}\text { Volume-carbon } \\
\text { relationship }\end{array}$ & $\begin{array}{r}\text { Faecal pellet carbon } \\
\text { content }\left(\mu \mathrm{mol} \mathrm{C} \text { pellet }^{-1}\right)\end{array}$ & $\begin{array}{l}\text { Faecal pellet carbon } \\
\text { content }\left(\mu \mathrm{g} \mathrm{C}_{\text {pellet }}{ }^{-1}\right)\end{array}$ \\
\hline Spherical & 4041 & $\begin{array}{r}11-1069 \\
150\end{array}$ & & $4 / 3 \pi(a / 2)^{3}$ & $\begin{array}{r}697-6.39 \times 10^{8} \\
1.77 \times \mathbf{1 0}^{\mathbf{6}}\end{array}$ & $0.036 \mathrm{mg} \mathrm{C} \mathrm{mm}^{-3 *}$ & $\begin{array}{r}2.09 \times 10^{-6}-1.91 \\
\mathbf{5 . 3} \mathbf{1 0}^{-3}\end{array}$ & $\begin{array}{r}2.51 \times 10^{-5}-23 \\
\mathbf{0 . 0 6}\end{array}$ \\
\hline Ovoid & 2047 & $\begin{array}{r}85-1132 \\
\mathbf{3 1 4}\end{array}$ & $\begin{array}{r}10-802 \\
\mathbf{1 5 4}\end{array}$ & $4 / 3 \pi(a / 2)(b / 2)^{2}$ & $\begin{aligned} 4.45 \times 10^{3}-3.81 & \times 10^{8} \\
\mathbf{3 . 9 0} & \times \mathbf{1 0}^{\mathbf{6}}\end{aligned}$ & & $\begin{array}{r}1.34 \times 10^{-5}-1.14 \\
\mathbf{1 1 . 7} \times \mathbf{1 0}^{-\mathbf{3}}\end{array}$ & $\begin{array}{r}1.60 \times 10^{-4}-13.72 \\
\mathbf{0 . 1 4}\end{array}$ \\
\hline Cylindrical & 1338 & $\begin{array}{r}106-6152 \\
\mathbf{9 8 1}\end{array}$ & $\begin{array}{r}14-547 \\
136\end{array}$ & $\pi(\mathrm{b} / 2)^{2} \mathrm{a}$ & $\begin{array}{r}1.63 \times 10^{4}-1.45 \times 10^{9} \\
\mathbf{1 . 4 3} \times \mathbf{1 0}^{\mathbf{7}}\end{array}$ & & $\begin{array}{r}4.89 \times 10^{-4}-4.35 \\
\mathbf{0 . 0 4}\end{array}$ & $\begin{array}{r}5.87 \times 10^{-4}-52 \\
\mathbf{0 . 5 1}\end{array}$ \\
\hline Ellipsoid & 54 & $\begin{array}{r}301-3893 \\
\mathbf{1 3 2 9}\end{array}$ & $\begin{array}{r}51-1051 \\
\mathbf{4 1 3}\end{array}$ & $4 / 3 \pi(a / 2)(b / 2)^{2}$ & $\begin{aligned} 4.10 \times 10^{5}-2.25 & \times 10^{9} \\
1.19 & \times 10^{8}\end{aligned}$ & & $\begin{array}{r}1.2 \times 10^{-3}-6.75 \\
\mathbf{0 . 3 6}\end{array}$ & $\begin{array}{r}0.01-81 \\
\mathbf{4 . 2 8}\end{array}$ \\
\hline Tabular & 29 & Highly vari & pes; see text & & & $\begin{array}{r}\text { Constant, } \\
119 \mu \mathrm{g} \mathrm{C}_{\text {pellet }}{ }^{-1 * *}\end{array}$ & 9.92 & 119 \\
\hline
\end{tabular}

* Conversion factor from Gonzalez and Smetacek (1994). ** Conversion factor from Wilson et al. (2013).
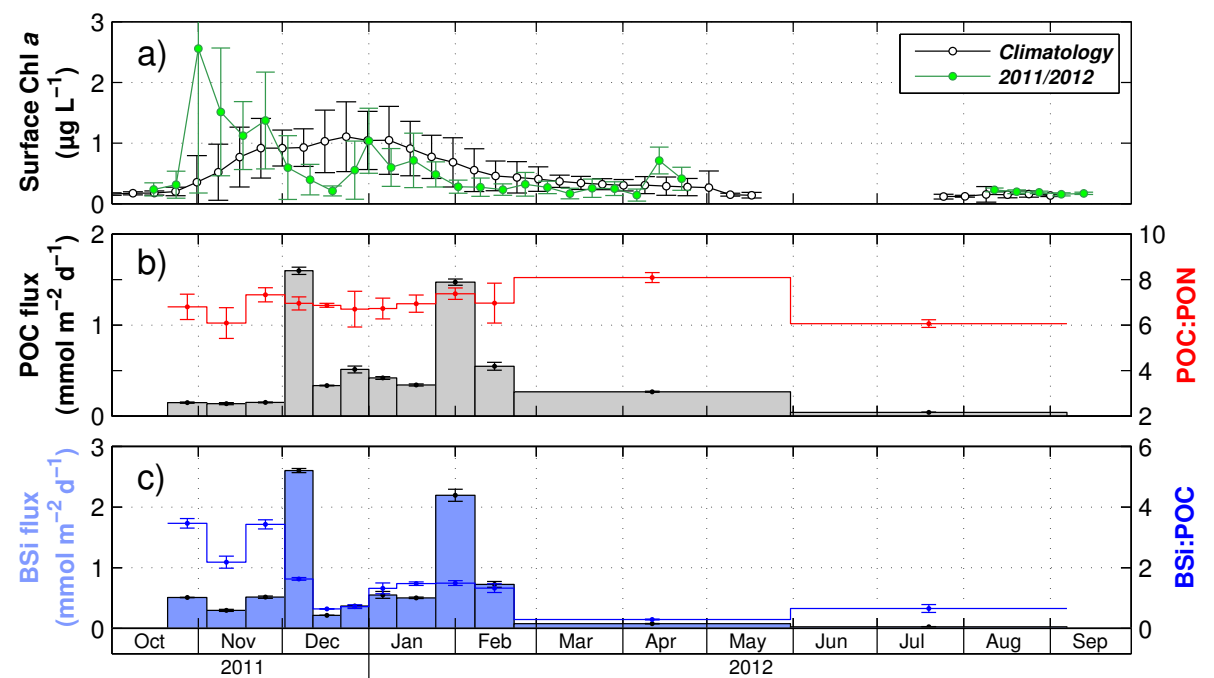

Figure 1. (a) Time series of the surface chlorophyll $a$ concentration averaged in a $100 \mathrm{~km}$ radius around the trap location. The black line represents the climatology calculated for the period 1997/2013, whilst the green line corresponds to the sediment trap deployment period (2011/2012). (b) POC fluxes (grey bars) and C/ N molar ratio (red line) of the exported material, (c) BSi flux (light-blue bars) and BSi : POC ratio (blue line). Error bars are standard deviations on triplicates.

\subsection{Diatom fluxes}

Diatoms from 33 taxa were identified and their fluxes determined across the 11-month time series. Fluxes are reported in Tables 4 and 5 for full and empty cells, respectively. Full and empty cell fluxes for the total community and for the taxa that are the major contributors to total diatom flux (eight taxa that account for $>1 \%$ of total cells annual export) are presented in Fig. 2. The full and empty cell fluxes for each diatom species or taxa are reported in Tables 4 and 5, respectively.

During spring (cups \#1 to \#3, October to December 2011) and autumn/winter (cups \#11 and \#12, February to September 2012) the total flux of full cells was $<5 \times 10^{6}$ cells m ${ }^{-2} \mathrm{~d}^{-1}$ (Fig. 2a). The total flux of full cells increased to 5.5 and $9.5 \times 10^{7}$ cells $\mathrm{m}^{-2} \mathrm{~d}^{-1}$ (cups \#4 and \#9, December and end of January, respectively) during two episodic (<14 days) sedimentation events. The two largest flux events (cups \#4 and \#9) were also associated with significant export of empty cells with respectively $6.1 \times 10^{7}$ and $2.9 \times 10^{7}$ cells $\mathrm{m}^{-2} \mathrm{~d}^{-1}$ (Fig. 2a). For Chaetoceros Hyalochaete spp. resting spores (CRS), full cell fluxes of $4 \times 10^{7}$ and $7.8 \times 10^{7}$ cells $\mathrm{m}^{-2} \mathrm{~d}^{-1}$ accounted for 76 and $83 \%$ of the total full cell flux during these two events, respectively (Fig. 2b), whereas a smaller contribution of Thalassiosira antarctica resting spores (TRS; $2.7 \times 10^{6}$ cells $\mathrm{m}^{-2} \mathrm{~d}^{-1}, 5 \%$ of total full cells) was observed during the first event (Fig. 2h). CRS also dominated (79$94 \%$ ) the composition of full cells in the intervening period (cups \#5 to \#8, December 2011 to January 2012), although the magnitude of cell flux was moderate $\left(9 \times 10^{6}\right.$ $2.5 \times 10^{7}$ cells $\mathrm{m}^{-2} \mathrm{~d}^{-1}$ ) by comparison (Fig. 2b). In cup 

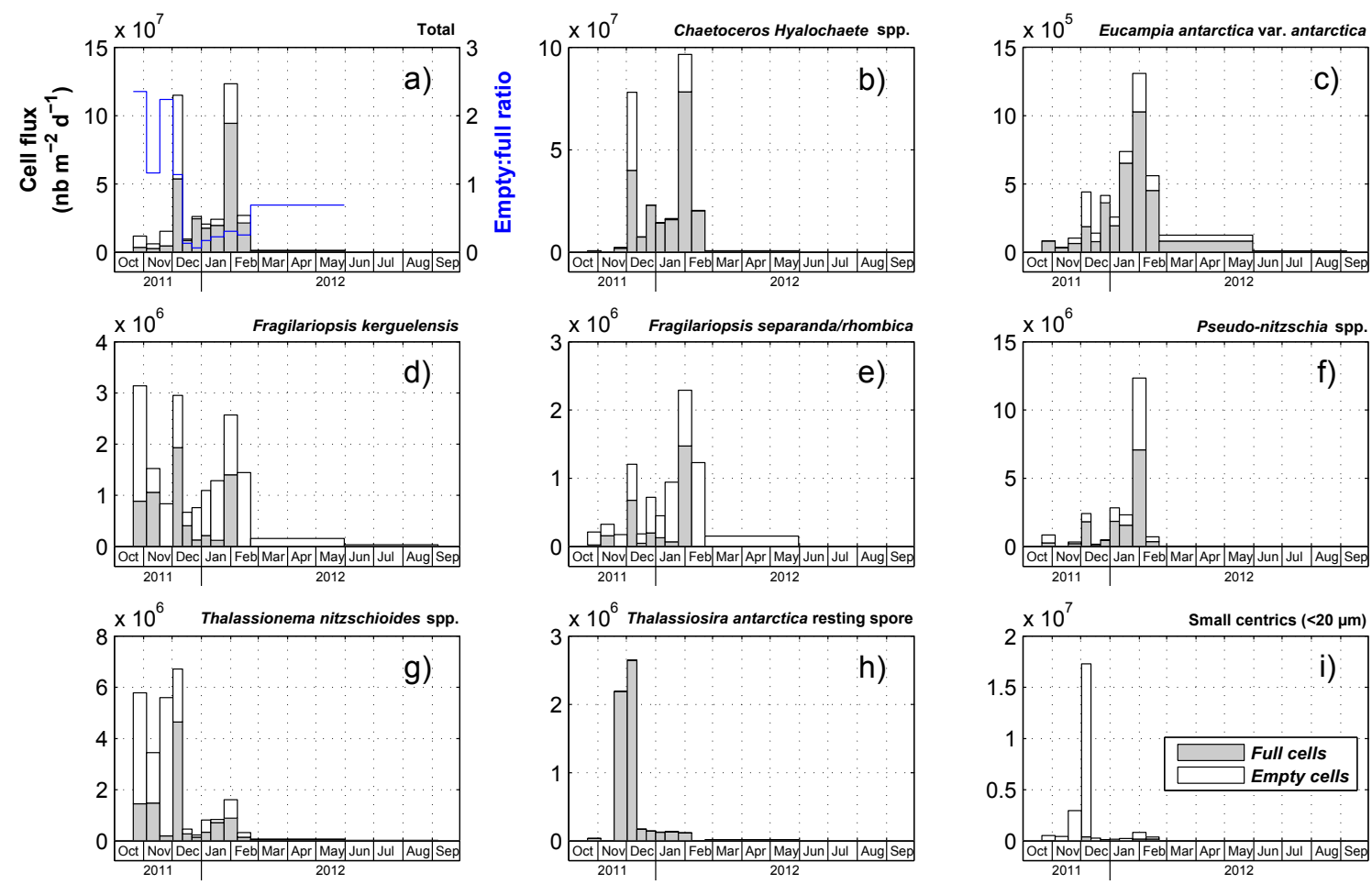

Figure 2. (a) Total diatom cell fluxes (bars, left axis) and total empty : full cell ratio (blue line, right axis). (b-h) Fluxes of diatom cells from selected species identified as major contributors to diatom fluxes (>1\% of total diatom fluxes). In (b), full cells are Chaetoceros Hyalochaete resting spores and empty cells are the vegetative stage. Full cell fluxes are represented by grey bars, whereas empty cell fluxes are represented by white bars.

\#4 (December 2011), the empty cell flux contained $61 \%$ Chaetoceros Hyalochaete spp. vegetative empty cells and $27 \%$ unidentified small centrics $(<20 \mu \mathrm{m})$ empty cells. In cup \#9 (end of January 2012), the total empty cell flux contained $60 \%$ Chaetoceros Hyalochaete spp. vegetative stage and only $2 \%$ small centrics $(<20 \mu \mathrm{m})$ empty cells.

Fragilariopsis kerguelensis and Fragilariopsis separanda/rhombica (Fig. 2d and e) were mostly exported from spring through the end of summer (cups \#1 to \#10, October 2011 to February 2012) with total (full + empty) fluxes $<3 \times 10^{6}$ cells m ${ }^{-2} \mathrm{~d}^{-1}$, a value $\sim 20$ times lower than the highest CRS fluxes recorded. During this time, these species were represented by $>50 \%$ of empty cells. In autumn and winter (cups \#10 and \#11, February to May 2012), these species were only represented by low fluxes $\left(<0.5 \times 10^{-6}\right.$ cells $\left.\mathrm{m}^{-2} \mathrm{~d}^{-1}\right)$ of empty cells. Thalassionema nitzschioides spp. fluxes were highest in spring and early summer (cups \#1 to \#4, October to December 2011), with total fluxes comprising between $3.5 \times 10^{6}$ and $6.7 \times 10^{6}$ cells m $\mathrm{m}^{-2} \mathrm{~d}^{-1}$ (Fig. $2 \mathrm{~g}$ ). The remainder of the year, total flux was $<2 \times 10^{6}$ cells $\mathrm{m}^{-2} \mathrm{~d}^{-1}$ and was essentially represented by full cells. Pseudo-nitzschia spp. were mostly represented by full cells (Fig. 2f) with the highest flux of $1.2 \times 10^{7}$ cells $\mathrm{m}^{-2} \mathrm{~d}^{-1}$ observed in the second intense export event (cup \#9, end of January 2012). Eucampia antarc- tica var.antarctica total fluxes were always represented by $>50 \%$ of full cells (Fig. 2c). Total cell fluxes of Eucampia antarctica var. antarctica gradually increased from $<1 \times 10^{5}$ to $1.3 \times 10^{6}$ cells m $\mathrm{m}^{-2} \mathrm{~d}^{-1}$ from spring to summer (cups \#1 to \#9, October 2011 to January 2012) and then decreased to a negligible flux in winter (cup \#12, May to September 2012). This species was observed as both the lightly silicified, chain-forming, vegetative form and the highly silicified winter growth stage form. Both forms were observed throughout the year without a specific seasonal pattern. Small centric species $(<20 \mu \mathrm{m})$ were essentially represented by empty cells (Fig. 2i). Their total fluxes were $<4 \times 10^{6}$ cells m ${ }^{-2} \mathrm{~d}^{-1}$, except in the first export event (cup \#4, December 2011), where their flux represented a considerable export of $1.7 \times 10^{7}$ cells m $\mathrm{m}^{-2} \mathrm{~d}^{-1}$.

Diatoms and sampling cup projection on the first two axes from the correspondence analysis is presented in Fig. 3. $\chi^{2}$ distance in the correspondence analysis is based on frequency distribution; therefore the results of the analysis must be considered as representative of the community composition as opposed to cell flux. The first two factors accounted for the majority $(75.6 \%)$ of total explained variance. Early in the season (cups \#1 to \#3, October to mid-December 2011), during the period of biomass accumulation in the surface (Fig. 1a), diatom fluxes were characterized by empty cells 
Table 4. Full diatoms cells flux $\left(10^{6} \mathrm{~m}^{-2} \mathrm{~d}^{-1}\right)$ from the station A3 sediment trap.

\begin{tabular}{|c|c|c|c|c|c|c|c|c|c|c|c|c|c|}
\hline \multirow[b]{2}{*}{ Species - taxa group } & \multicolumn{12}{|c|}{ Cup number } & \multirow{2}{*}{$\begin{array}{l}\text { Contribution to } \\
\text { annual full } \\
\text { cells flux (\%) }\end{array}$} \\
\hline & 1 & 2 & 3 & 4 & 5 & 6 & 7 & 8 & 9 & 10 & 11 & 12 & \\
\hline Asteromphalus spp. & 0 & 0.01 & 0 & 0.03 & 0 & 0 & 0 & 0 & 0.12 & 0 & 0 & 0 & 0.1 \\
\hline Chaetoceros atlanticus Cleve & 0 & 0 & 0 & 0 & 0 & 0 & 0 & 0 & 0.07 & 0 & 0 & 0 & 0.0 \\
\hline Chaetoceros atlanticus f. bulbosus Ehrenberg & 0 & 0 & 0 & 0 & 0 & 0 & 0 & 0 & 0 & 0 & 0 & 0 & 0.0 \\
\hline Chaetoceros decipiens Cleve & 0 & 0 & 0.02 & 0 & 0 & 0 & 0 & 0 & 0.07 & 0 & 0 & 0 & 0.0 \\
\hline Chaetoceros dichaeta Ehrenberg & 0 & 0 & 0 & 0.07 & 0 & 0 & 0 & 0 & 0.26 & 0 & 0 & 0 & 0.1 \\
\hline Chaetoceros Hyalochaete spp.* & 0.70 & 0 & 1.95 & 39.92 & 7.42 & 23.04 & 14.37 & 15.88 & 78.29 & 20.24 & 0.68 & 0 & 80.2 \\
\hline Corethron inerme Karsten & 0 & 0 & 0 & 0 & 0 & 0 & 0 & 0 & 0.23 & 0 & 0 & 0 & 0.1 \\
\hline Corethron pennatum Grunow & 0 & 0 & 0 & 0 & 0 & 0 & 0 & 0 & 0 & 0 & 0 & 0 & 0.0 \\
\hline Dactyliosolen antarcticus Castracane & 0 & 0 & 0 & 0.05 & 0 & 0 & 0 & 0 & 0.02 & 0 & 0 & 0 & 0.0 \\
\hline $\begin{array}{l}\text { Eucampia antarctica var. } \\
\text { antarctica (Castracane) Mangin }\end{array}$ & 0.08 & 0.03 & 0.06 & 0.19 & 0.08 & 0.36 & 0.19 & 0.65 & 1.03 & 0.45 & 0.08 & 0.01 & 1.6 \\
\hline Fragilariopsis kerguelensis (O'Meara) Hustedt & 0.88 & 1.06 & 0 & 1.93 & 0.40 & 0.13 & 0.21 & 0.12 & 1.40 & 0 & 0 & 0 & 2.4 \\
\hline Fragilariopsis separanda/rhombica group & 0.02 & 0.16 & 0 & 0.68 & 0.05 & 0.20 & 0.13 & 0.07 & 1.47 & 0 & 0 & 0 & 1.1 \\
\hline Guinardia cylindrus (Cleve) Hasle & 0 & 0 & 0 & 0 & 0 & 0 & 0 & 0 & 0.07 & 0 & 0 & 0 & 0.0 \\
\hline Leptocylindrus sp. & 0 & 0 & 0 & 0.03 & 0 & 0 & 0 & 0 & 0 & 0 & 0 & 0 & 0.0 \\
\hline Membraneis spp. & 0.04 & 0.01 & 0 & 0.19 & 0 & 0 & 0.02 & 0.02 & 0.02 & 0 & 0 & 0 & 0.1 \\
\hline Navicula spp. & 0 & 0 & 0.04 & 0.64 & 0 & 0 & 0 & 0.29 & 0.58 & 0 & 0 & 0 & 0.6 \\
\hline Odontella weissflogii (Grunow) Grunow & 0 & 0 & 0 & 0.08 & 0 & 0 & 0 & 0 & 0.05 & 0 & 0 & 0 & 0.0 \\
\hline Pleurosigma spp. & 0.01 & 0 & 0 & 0.22 & 0.02 & 0.02 & 0 & 0.03 & 0.96 & 0.04 & 0 & 0 & 0.5 \\
\hline Proboscia alata (Brightwell) Sundröm & 0 & 0 & 0 & 0 & 0 & 0 & 0 & 0 & 0.09 & 0 & 0 & 0 & 0.0 \\
\hline $\begin{array}{l}\text { Proboscia inermis (Castracane) } \\
\text { Jordan \& Ligowski }\end{array}$ & 0 & 0 & 0 & 0.03 & 0 & 0 & 0 & 0 & 0.33 & 0 & 0 & 0 & 0.2 \\
\hline $\begin{array}{l}\text { Proboscia truncata (Karsten) } \\
\text { Nöthig \& Logowski }\end{array}$ & 0 & 0 & 0 & 0 & 0 & 0 & 0 & 0 & 0 & 0 & 0 & 0 & 0.0 \\
\hline Pseudo-nitzschia spp. & 0.26 & 0.02 & 0.21 & 1.81 & 0.08 & 0.45 & 1.85 & 1.56 & 7.08 & 0.36 & 0.02 & 0 & 5.6 \\
\hline Rhizosolenia antennata/styliformis group & 0 & 0 & 0 & 0 & 0 & 0 & 0 & 0 & 0.05 & 0 & 0 & 0 & 0.0 \\
\hline Rhizosolenia chunii Karsten & 0 & 0 & 0 & 0 & 0.05 & 0 & 0 & 0.03 & 0.07 & 0 & 0 & 0 & 0.1 \\
\hline Rhizosolenia crassa Schimper in Karsten & 0 & 0 & 0 & 0 & 0 & 0 & 0 & 0 & 0 & 0 & 0 & 0 & 0.0 \\
\hline Rhizosolenia simplex Karsten & 0 & 0 & 0 & 0 & 0 & 0 & 0 & 0 & 0.07 & 0 & 0 & 0 & 0.0 \\
\hline $\begin{array}{l}\text { Thalassionema nitzschioides spp. } \\
\text { Pergallo \& Pergallo }\end{array}$ & 1.45 & 1.48 & 0.20 & 4.65 & 0.28 & 0.14 & 0.34 & 0.72 & 0.89 & 0.14 & 0.05 & 0.01 & 4.0 \\
\hline Thalassiosira lentiginosa (Janisch) Fryxell & 0.01 & 0 & 0 & 0 & 0 & 0 & 0 & 0 & 0 & 0 & 0 & 0 & 0.0 \\
\hline Thalassiosira spp. & 0 & 0.05 & 0 & 0.05 & 0 & 0 & 0 & 0 & 0.12 & 0.05 & 0 & 0 & 0.1 \\
\hline $\begin{array}{l}\text { Thalassiosira antarctica resting } \\
\text { spore (TRS) Comber }\end{array}$ & 0.04 & 0 & 2.19 & 2.65 & 0.17 & 0.14 & 0.13 & 0.14 & 0.12 & 0 & 0.01 & 0 & 2.1 \\
\hline Thalassiothrix antarctica Schimper ex Karsten & 0 & 0 & 0 & 0.02 & 0.05 & 0.04 & 0.34 & 0.14 & 0.70 & 0 & 0 & 0 & 0.5 \\
\hline Small centrics $(<20 \mu \mathrm{m})$ & 0.05 & 0 & 0 & 0.41 & 0 & 0 & 0 & 0 & 0.19 & 0.18 & 0 & 0 & 0.3 \\
\hline Large centrics $(>20 \mu \mathrm{m})$ & 0 & 0 & 0.05 & 0.08 & 0 & 0 & 0 & 0 & 0.05 & 0 & 0 & 0 & 0.1 \\
\hline Total full cells & 35.39 & 28.20 & 47.18 & 537.38 & 85.85 & 245.20 & 175.89 & 196.56 & 943.88 & 214.65 & 8.46 & 0.22 & \\
\hline
\end{tabular}

* Full cells of Chaetoceros Hyalochaete spp. were only found as resting spores.

of T. nitzschioides spp. and F. kerguelensis. Full TRS cells were observed in cup \#3 (end of November 2011) following the initial bloom decline. The first major flux event (cup \#4, December 2011) contained mostly TRS, empty small centrics $(<20 \mu \mathrm{m})$ cells and empty Chaetoceros Hyalochaete spp. cells. The summer flux period (cups \#5 to \#8, December 2011 to January 2012) primarily consisted of CRS, although E. antarctica var. antarctica, Pseudo-nitzschia spp. and Thalassiothrix antarctica were present as full cells and Plagiotropis spp., Membraneis spp., Pseudo-nitzschia spp. as empty cells. The second major flux event (cup \#9, end of January 2012) was tightly associated with CRS and full Pseudonitzschia spp. cells. Subsequent cups (\#10 and \#11, February to May 2012) were characterized by full cells of E. antarctica var. antarctica and Thalassiothrix antarctica and empty cells of Corethron inerme, P. alata, F. separanda/rhombica and F. kerguelensis. Winter fluxes (cup \#12, May to September 2012) were similar to the initial three cups characterized pri- marily by empty cells of small diatom taxa. The centralized projection in Fig. 3 of full F. kerguelensis and T. nitzschioides spp. highlights their constant presence throughout the annual record.

The total empty: full cell ratio is presented in Fig. 2a (blue line). This ratio was highest in spring and early summer (cups \#1 to \#4, October to December 2011), ranging between 1.1 and 2.4, suggesting more empty cells to full cells. The ratio was lowest, representing considerably more full cells to empty cells in cups \#5 to \#10 (December 2011 to February 2012) with values between 0.1 and 0.4 . In autumn (cup \#11, February to May 2012), the empty : full ratio increased to 0.7. In the winter cup \#12 (May to September 2012), the total amount of full diatom cells was very low and therefore we could not calculate a robust empty: full ratio. Across the time series, certain diatom taxa were observed exclusively as empty cells, notably Chaetoceros atlanticus f. bulbosus and Corethron pennatum. For diatom 
Table 5. Empty diatoms cells flux $\left(10^{6} \mathrm{~m}^{-2} \mathrm{~d}^{-1}\right)$ from the station A3 sediment trap.

\begin{tabular}{|c|c|c|c|c|c|c|c|c|c|c|c|c|c|}
\hline \multirow[b]{2}{*}{ Species - taxa group } & \multicolumn{12}{|c|}{ Cup number } & \multirow{2}{*}{$\begin{array}{l}\text { Contribution to } \\
\text { annual empty } \\
\text { cells flux (\%) }\end{array}$} \\
\hline & 1 & 2 & 3 & 4 & 5 & 6 & 7 & 8 & 9 & 10 & 11 & 12 & \\
\hline Asteromphalus spp. & 0.02 & 0.02 & 0.09 & 0.08 & 0 & 0.05 & 0 & 0.03 & 0.05 & 0 & 0 & 0 & 0.3 \\
\hline Chaetoceros atlanticus Cleve & 0 & 0 & 0 & 0 & 0 & 0 & 0 & 0 & 0 & 0 & 0 & 0 & 0.0 \\
\hline Chaetoceros atlanticus f. bulbosus Ehrenberg & 0.01 & 0 & 0 & 0 & 0 & 0 & 0 & 0.02 & 0 & 0.02 & 0 & 0 & 0.0 \\
\hline Chaetoceros decipiens Cleve & 0 & 0 & 0.02 & 0.24 & 0 & 0 & 0 & 0 & 0 & 0 & 0 & 0 & 0.2 \\
\hline Chaetoceros dichaeta Ehrenberg & 0 & 0 & 0.06 & 0.07 & 0 & 0 & 0 & 0 & 0.05 & 0 & 0.01 & 0 & 0.2 \\
\hline Chaetoceros Hyalochaete spp. & 0 & 0 & 0.45 & 38.19 & 0 & 0 & 0 & 0.60 & 18.23 & 0.18 & 0 & 0 & 41.2 \\
\hline Corethron inerme Karsten & 0.01 & 0.01 & 0.04 & 0 & 0 & 0.02 & 0 & 0 & 0.23 & 0.31 & 0.06 & 0 & 0.9 \\
\hline Corethron pennatum Grunow & 0 & 0 & 0.02 & 0 & 0 & 0 & 0 & 0.02 & 0 & 0 & 0.01 & 0 & 0.1 \\
\hline Dactyliosolen antarcticus Castracane & 0 & 0 & 0 & 0.05 & 0 & 0 & 0 & 0.07 & 0.02 & 0.05 & 0 & 0 & 0.2 \\
\hline $\begin{array}{l}\text { Eucampia antarctica var. } \\
\text { antarctica (Castracane) Mangin }\end{array}$ & 0 & 0 & 0.04 & 0.25 & 0.06 & 0.05 & 0.06 & 0.09 & 0.28 & 0.11 & 0.04 & 0 & 1.0 \\
\hline Fragilariopsis kerguelensis (O'Meara) Hustedt & 2.25 & 0.46 & 0.84 & 1.02 & 0.26 & 0.63 & 0.88 & 1.17 & 1.17 & 1.45 & 0.16 & 0.03 & 9.4 \\
\hline Fragilariopsis separanda/rhombica group & 0.19 & 0.17 & 0.18 & 0.53 & 0.14 & 0.52 & 0.32 & 0.87 & 0.82 & 1.23 & 0.15 & 0 & 5.0 \\
\hline Guinardia cylindrus (Cleve) Hasle & 0 & 0 & 0 & 0 & 0 & 0 & 0 & 0 & 0 & 0 & 0 & 0 & 0.0 \\
\hline Leptocylindrus sp. & 0 & 0 & 0 & 0 & 0 & 0 & 0 & 0 & 0 & 0 & 0 & 0 & 0.0 \\
\hline Membraneis spp. & 0 & 0 & 0.02 & 0.05 & 0.02 & 0.04 & 0.02 & 0.07 & 0.14 & 0.07 & 0.01 & 0 & 0.4 \\
\hline Navicula spp. & 0 & 0 & 0.13 & 0.36 & 0 & 0 & 0 & 0.12 & 0.12 & 0 & 0 & 0 & 0.5 \\
\hline Odontella weissflogii (Grunow) Grunow & 0 & 0 & 0.02 & 0.10 & 0 & 0 & 0 & 0.02 & 0 & 0.02 & 0 & 0 & 0.1 \\
\hline Pleurosigma spp. & 0.18 & 0.06 & 0.08 & 0.41 & 0.08 & 0 & 0.09 & 0.12 & 0.93 & 0.38 & 0.03 & 0 & 2.1 \\
\hline Proboscia alata (Brightwell) Sundröm & 0 & 0 & 0 & 0 & 0 & 0 & 0 & 0.03 & 0.05 & 0.34 & 0.01 & 0 & 0.5 \\
\hline $\begin{array}{l}\text { Proboscia inermis (Castracane) } \\
\text { Jordan \& Ligowski }\end{array}$ & 0 & 0 & 0.01 & 0.08 & 0 & 0 & 0 & 0.03 & 0.05 & 0.13 & 0.01 & 0 & 0.3 \\
\hline $\begin{array}{l}\text { Proboscia truncata (Karsten) } \\
\text { Nöthig \& Logowski }\end{array}$ & 0 & 0 & 0.02 & 0 & 0 & 0 & 0 & 0 & 0 & 0.02 & 0 & 0 & 0.0 \\
\hline Pseudo-nitzschia spp. & 0.59 & 0 & 0.12 & 0.59 & 0.09 & 0.04 & 0.99 & 0.75 & 5.26 & 0.34 & 0.02 & 0 & 7.4 \\
\hline Rhizosolenia antennata/styliformis group & 0 & 0 & 0 & 0 & 0 & 0 & 0 & 0.02 & 0.02 & 0.13 & 0 & 0 & 0.2 \\
\hline Rhizosolenia chunii Karsten & 0 & 0 & 0 & 0.03 & 0 & 0 & 0 & 0.02 & 0.02 & 0.20 & 0.02 & 0 & 0.4 \\
\hline Rhizosolenia crassa Schimper in Karsten & 0 & 0 & 0 & 0 & 0 & 0 & 0 & 0 & 0 & 0.04 & 0 & 0 & 0.0 \\
\hline Rhizosolenia simplex Karsten & 0 & 0 & 0 & 0 & 0 & 0 & 0 & 0.02 & 0 & 0 & 0 & 0 & 0.0 \\
\hline $\begin{array}{l}\text { Thalassionema nitzschioides spp. } \\
\text { Pergallo \& Pergallo }\end{array}$ & 4.33 & 1.97 & 5.39 & 2.07 & 0.19 & 0.09 & 0.47 & 0.12 & 0.72 & 0.18 & 0.03 & 0.01 & 13.2 \\
\hline Thalassiosira lentiginosa (Janisch) Fryxell & 0.25 & 0.06 & 0.10 & 0 & 0 & 0 & 0 & 0 & 0 & 0 & 0 & 0 & 0.4 \\
\hline Thalassiosira spp. & 0.02 & 0.06 & 0.01 & 0 & 0 & 0 & 0 & 0 & 0 & 0 & 0 & 0 & 0.1 \\
\hline $\begin{array}{l}\text { Thalassiosira antarctica resting } \\
\text { spore (TRS) Comber }\end{array}$ & 0 & 0 & 0 & 0 & 0 & 0 & 0 & 0 & 0 & 0 & 0 & 0 & 0.0 \\
\hline Thalassiothrix antarctica Schimper ex Karsten & 0 & 0 & 0 & 0 & 0 & 0.02 & 0 & 0 & 0 & 0.04 & 0 & 0 & 0.0 \\
\hline Small centrics $(<20 \mu \mathrm{m})$ & 0.48 & 0.44 & 2.96 & 16.87 & 0.28 & 0.13 & 0.17 & 0.24 & 0.65 & 0.20 & 0.03 & 0.02 & 15.7 \\
\hline Large centrics $(>20 \mu \mathrm{m})$ & 0 & 0.03 & 0.01 & 0.20 & 0 & 0 & 0 & 0 & 0.16 & 0.04 & 0 & 0 & 0.3 \\
\hline Total empty cells & 8.34 & 3.28 & 10.57 & 61.20 & 1.12 & 1.59 & 3.01 & 4.43 & 28.98 & 5.46 & 0.59 & 0.07 & \\
\hline
\end{tabular}

taxa present as full and empty cells we calculated an annually integrated empty: full ratio (Fig. 4) and arbitrarily defined threshold values of 2 (representing species mainly observed as empty cells) and 0.5 (representing species mainly observed as full cells). In decreasing order, the diatom taxa exhibiting empty : full ratios $>2$ were Thalassiosira lentiginosa, small centrics $(<20 \mu \mathrm{m})$, Proboscia alata, Rhizosolenia antennata/styliformis, Chaetoceros decipiens, Corethron inerme, Dactyliosolen antarcticus, large centrics (> $20 \mu \mathrm{m})$, and Asteromphalus spp. The diatom taxa displaying an empty : full ratio < 0.5 were Thalassiothrix antarctica, Rhizosolenia simplex CRS, Eucampia antarctica var. antarctica, Thalassiosira spp. and Navicula spp. Species or grouped taxa with ratio values falling between the thresholds $<2$ and $>0.5$ (R. chunii, through to $C$. dichaeta in Fig. 4) were perceived as being almost equally represented by full and empty cells when integrated annually across the time series.

\subsection{Faecal pellet fluxes}

The seasonal flux of faecal pellet type, and volume and their estimated carbon flux are summarized in Fig. 5 and Table 6. Total faecal pellet flux was $<2 \times 10^{3}$ pellets $\mathrm{m}^{-2} \mathrm{~d}^{-1}$ in spring (cups \#1 to \#3, October to December 2011). Cups \#4 and \#5 (December 2011) were characterized by the highest fluxes of $21.8 \times 10^{3}$ and $5.1 \times 10^{3}$ pellets $\mathrm{m}^{-2} \mathrm{~d}^{-1}$ (Fig. 5a, Table 6). Faecal pellet numerical flux decreased gradually from mid-summer (cup \#5, December 2011) to reach a minimal value in winter (140 pellets $\mathrm{m}^{-2} \mathrm{~d}^{-1}$ in cup \#12, May to September 2012). In spring (cups \#1 to \#3, October to December 2011), spherical and cylindrical shapes dominated the numerical faecal pellet fluxes. Ellipsoid and tab- 


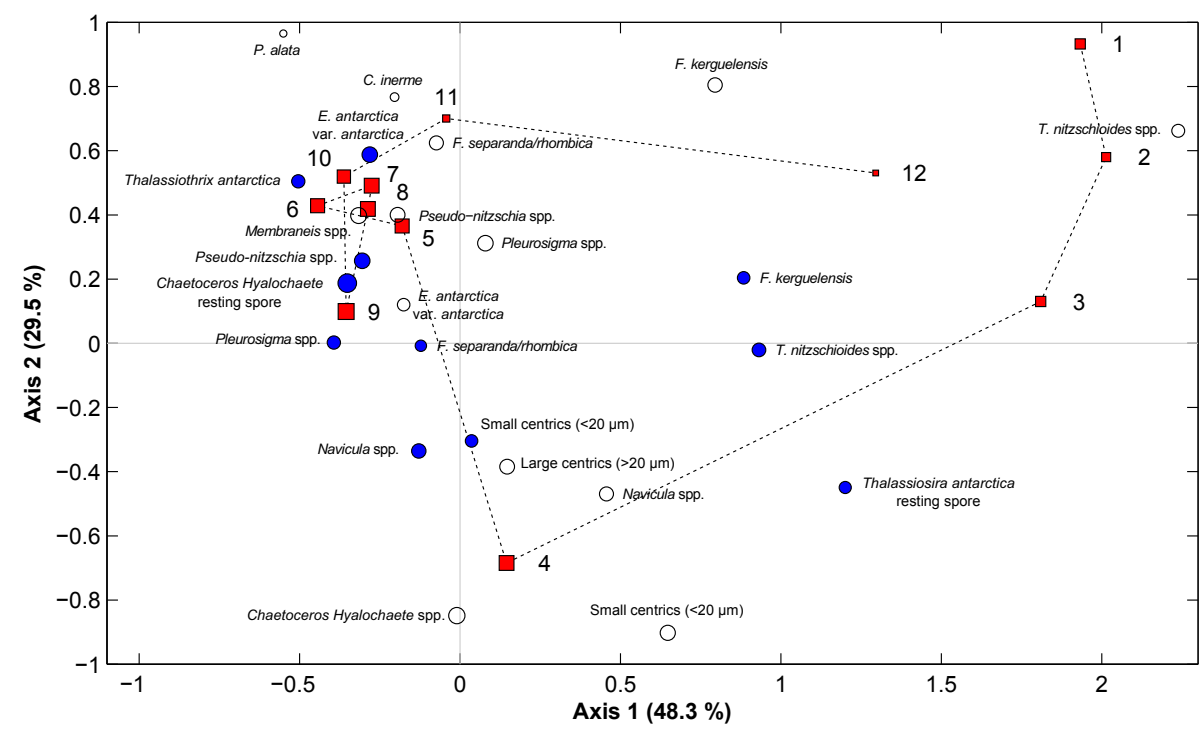

Figure 3. Factorial map constituted by the first two axes of the correspondence analysis performed on the full and empty diatom cell fluxes. Red squares are cup projections with cup numbers specified, blue circles are full cell projections and white circles are empty cell projections. The size of the markers is proportional to their representation quality in this factorial map.

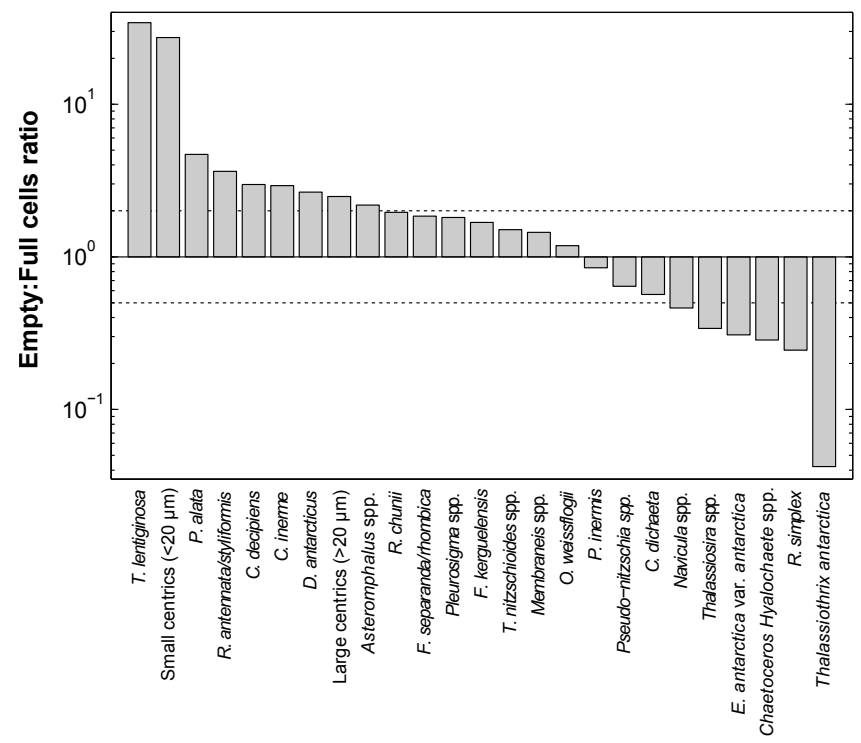

Figure 4. Annual ratio of empty to full cells for species observed as both forms. The dashed lines are the 0.5 and 2 ratio values. Chaetoceros Hyalochaete spp. full cells were only observed as resting spores.

ular shapes were absent from these spring cups. The first export event (cup \#4, December 2011) was numerically dominated by the spherically shaped pellets; however the remainder of the summer (cups \#5 to \#10, December 2011 to February 2012) contained spherical, ovoid and cylindrical shapes in comparable proportions. Ellipsoid shapes were observed from mid-summer to autumn (cups \#7 to \#11, January to May 2012), but their overall contribution to pellet flux was low ( $<6 \%$, Table 6). Rare tabular shapes were observed in summer (cups \#6 and \#8, December and January 2012) and their contribution to numerical fluxes was highest in autumn and winter (cups \#11 and \#12, February to September 2012).

The median faecal pellet volume showed a seasonal signal, with a maximum peak $>5.5 \times 10^{6} \mu \mathrm{m}^{3}$ in mid-summer (cups \# 6 to \#8, mid-December to January 2012) and values $<4 \times 10^{6} \mu^{3}$ the remainder of the year (Fig. 5b). Concomitantly with the highest median volume, the largest variance in faecal pellet size was also observed in the summer (highest interquartile values in Fig. 5b).

Total faecal pellet carbon flux was lowest in spring $\left(<0.05 \mathrm{mmol} \mathrm{C} \mathrm{m}^{-2} \mathrm{~d}^{-1}\right.$ in cups \#1 to \#3, October to December 2011, Fig. 5c, Table 6). The highest total faecal pellet carbon flux of nearly $0.5 \mathrm{mmol} \mathrm{C} \mathrm{m}{ }^{-2} \mathrm{~d}^{-1}$ was observed during the first export event in cup \#4 (December 2011) and was essentially composed of spherical shapes $(83 \%$, Table 6). For the remainder of the summer (cups \#5 to \#10, December 2011 to February 2012), total faecal pellet carbon flux was between 0.03 and $0.15 \mathrm{mmol} \mathrm{C} \mathrm{m}^{-2} \mathrm{~d}^{-1}$, with a dominant contribution of cylindrical, ellipsoid and tabular shapes. In autumn and winter (cups \#11 and \#12, February to September 2012), faecal pellet carbon fluxes of 0.13 and $0.06 \mathrm{mmol} \mathrm{C} \mathrm{m}^{-2} \mathrm{~d}^{-1}$ were strictly dominated by tabular shapes (>90\% to total faecal pellet carbon fluxes, Table 6 ).

\subsection{Statistical analysis of biological and biogeochemical signatures}

The $\beta$ correlation coefficients of standardized variables obtained from the PLSR analysis are presented as a heat map in Fig. 6. The full cell fluxes of all diatom taxa, in addition 
Table 6. Faecal pellet numerical fluxes (normal text) and contribution to faecal pellet carbon fluxes (bold) from the station A3 sediment trap.

\begin{tabular}{|c|c|c|c|c|c|c|c|c|}
\hline \multirow[b]{2}{*}{ Cup } & \multirow[b]{2}{*}{$\begin{array}{r}\text { Total FP flux } \\
\left(\mathrm{nb} \mathrm{m}^{-2} \mathrm{~d}^{-1}\right) \times 10^{3}\end{array}$} & \multirow[b]{2}{*}{$\begin{array}{l}\text { Total FP carbon flux } \\
\qquad\left(\mathrm{mmol} \mathrm{m}^{-2} \mathrm{~d}^{-1}\right)\end{array}$} & \multirow[b]{2}{*}{$\begin{array}{r}\text { Median volume } \\
\qquad\left(10^{6} \mu \mathrm{m}^{3}\right)\end{array}$} & \multicolumn{5}{|c|}{ Contribution (\%) } \\
\hline & & & & Spherical & Ovoid & Cylindrical & Ellipsoid & Tabular \\
\hline \multirow[t]{2}{*}{1} & 1.39 & 0.02 & 2.07 & 53.3 & 19.7 & 27.0 & 0.0 & 0.0 \\
\hline & & & & 36.8 & 18.6 & 44.6 & 0.0 & 0.0 \\
\hline \multirow[t]{2}{*}{2} & 1.75 & 0.04 & 3.55 & 36.5 & 29.7 & 33.9 & 0.0 & 0.0 \\
\hline & & & & 22.4 & 21.3 & 56.3 & 0.0 & 0.0 \\
\hline \multirow[t]{2}{*}{3} & 0.72 & $<0.01$ & 0.95 & 62.7 & 37.3 & 0.0 & 0.0 & 0.0 \\
\hline & & & & 54.5 & 45.5 & 0.0 & 0.0 & 0.0 \\
\hline \multirow[t]{2}{*}{4} & 21.81 & 0.48 & 1.91 & 76.4 & 22.8 & 0.8 & 0.0 & 0.0 \\
\hline & & & & 83.1 & 15.3 & 1.6 & $\mathbf{0 . 0}$ & 0.0 \\
\hline \multirow[t]{2}{*}{5} & 5.10 & 0.12 & 3.71 & 26.6 & 35.0 & 38.3 & 0.1 & 0.0 \\
\hline & & & & 13.8 & 18.3 & 67.4 & 0.5 & 0.0 \\
\hline \multirow[t]{2}{*}{6} & 2.69 & 0.15 & 5.67 & 28.8 & 33.1 & 37.9 & 0.0 & 0.2 \\
\hline & & & & 4.6 & 10.9 & 43.1 & 0.0 & 41.3 \\
\hline \multirow[t]{2}{*}{7} & 2.46 & 0.12 & 6.71 & 15.6 & 45.5 & 37.1 & 1.8 & 0.0 \\
\hline & & & & 2.5 & 16.1 & 56.0 & 25.3 & 0.0 \\
\hline \multirow[t]{2}{*}{8} & 2.06 & 0.20 & 6.18 & 37.6 & 15.5 & 44.2 & 2.2 & 0.4 \\
\hline & & & & 1.9 & 2.1 & 34.6 & 15.8 & 45.5 \\
\hline \multirow[t]{2}{*}{9} & 1.36 & 0.09 & 3.59 & 40.4 & 20.5 & 35.4 & 3.7 & 0.0 \\
\hline & & & & 2.8 & 4.9 & 27.9 & 64.4 & 0.0 \\
\hline \multirow[t]{2}{*}{10} & 1.22 & 0.03 & 2.34 & 56.0 & 22.4 & 21.3 & 0.4 & 0.0 \\
\hline & & & & 17.7 & 9.1 & 69.9 & 3.3 & 0.0 \\
\hline \multirow[t]{2}{*}{11} & 0.27 & 0.13 & 2.10 & 38.9 & 30.8 & 20.3 & 5.7 & 4.3 \\
\hline & & & & 0.4 & 0.7 & 2.5 & 3.9 & 92.6 \\
\hline \multirow[t]{4}{*}{12} & 0.14 & 0.06 & 2.41 & 18.4 & 57.6 & 20.3 & 0.0 & 3.7 \\
\hline & & & & 0.4 & 2.6 & 5.3 & 0.0 & 91.8 \\
\hline & \multirow{2}{*}{\multicolumn{2}{|c|}{$\begin{array}{l}\text { Annually integrated contribution } \\
\text { to faecal pellet flux }\end{array}$}} & & 53.8 & 27.3 & 17.8 & 0.7 & 0.4 \\
\hline & & & & 17.9 & 6.6 & 17.3 & 7.7 & 50.4 \\
\hline
\end{tabular}

to spherical and ovoid and ellipsoid faecal pellet fluxes were positively correlated with POC and PON fluxes. By contrast, empty cell fluxes of $F$. kerguelensis, $P$. alata, $T$. nitzschioides spp. and T. lentiginosa as well as cyclindrical, ellipsoid and tabular pellet fluxes were either uncorrelated or negatively correlated with POC and PON fluxes. Full and empty cell fluxes of all diatom taxa were positively correlated with $\mathrm{BSi}$ fluxes, although this correlation was notably weak for empty cells of $C$. inerme, P. alata and T. lentiginosa. Only spherical and ovoid faecal pellets were positively correlated with $\mathrm{BSi}$ fluxes. Full cell fluxes of CRS and E. antarctica var. antarctica were the most negatively correlated with BSi : POC molar ratio, whereas TRS, F. kerguelensis, T. nitzschioides spp. and T. lentiginosa full cell fluxes were positively correlated. Spherical and ovoid faecal pellets were weakly and negatively correlated with the $\mathrm{BSi}$ : $\mathrm{POC}$ molar ratio, whereas the cylindrical, ellipsoid and tabular shapes were more strongly negatively correlated with the BSi : POC molar ratio. All the biological components exhibited weak or no correlations to the POC: PON molar ratio.

The first two latent vectors of the PLSR accounted for 61.3 and $74.1 \%$ of cumulative variance in $X$ (full and empty di- atom and pellet fluxes) and $Y$ (biogeochemical properties). In order to show how the seasonal succession of flux vectors was related to the bulk geochemical properties of particles, the sampling cups, biological and chemical factors were projected on the first two latent factors of the PLSR analysis (Fig. 7). Positively projected on the first axis are the POC, PON and BSi fluxes, close to the export events sampled in cups \#4 (December 2011) and \#9 (end of January 2012). The closest biological components comprise a complex assemblage of full and empty cells and spherical and ovoid faecal pellet shapes. All the other cups are projected far from these two export events. Spring cups (\#1 to \#3, October to midDecember 2011) are opposite to the autumn (\#11, February to May 2012) and winter (\#12, May to September 2012) cups on the second axis. Empty frustules of F. kerguelensis, $T$. lentiginosa and T. nitzschioides spp. are projected close to the spring cups (\#1 to \#3, October to mid-December 2011) together with the BSi:POC molar ratio, whereas autumn (\#11, February to May 2012) and winter cups (\#12, May to September 2012) are projected far from the BSi : POC molar ratio and close to the tabular and cylindrical faecal pellet shapes. 

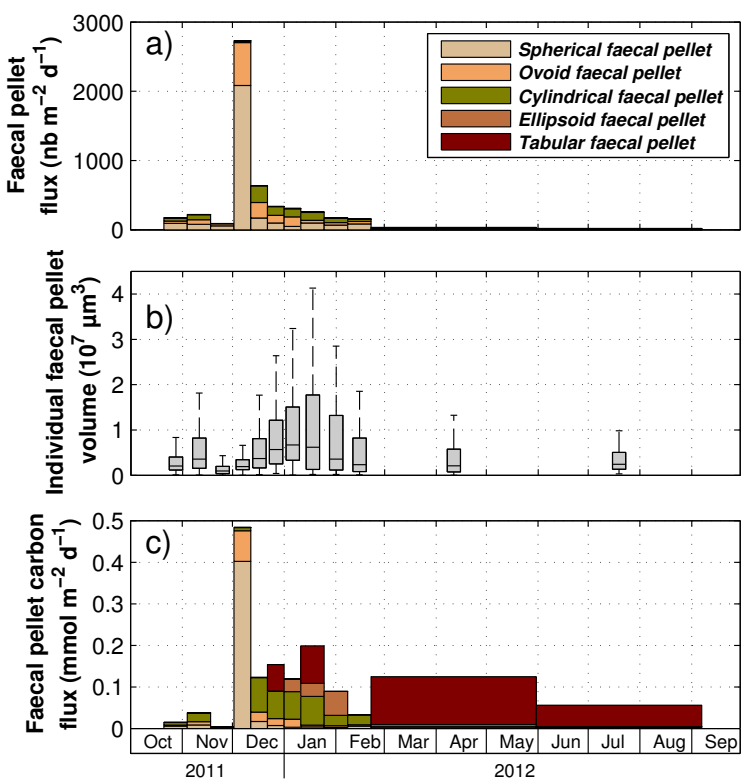

Figure 5. (a) Faecal pellet numerical fluxes partitioned among faecal pellet types and (b) box plot of faecal pellet volume. On each box, the central mark is the median, the edges of the box are the first and third quartiles, and the whiskers extend to the most extreme data points comprised in 1.5 times the interquartile distance. (c) Faecal pellet carbon fluxes partitioned between the five faecal pellet types. The two arrows represent the two strong POC export events (cup \#4 and \#9, December 2011 and end of January 2012, respectively).

\subsection{Partitioning carbon fluxes among ecological vectors}

We estimated the contribution of resting spores and faecal pellets to carbon flux, calculated their cumulative values and compared them to measured values (Fig. 8a and b). A highly significant correlation (Spearman rank correlation, $n=36, \rho=0.84, p<0.001$ ) was evident between calculated and measured carbon flux, suggesting that the main ecological flux vectors observed in the sample were capable of explaining the seasonal variation in total POC flux. Table 7 lists the contribution of each vector to the calculated flux. In cup \#1 (October to mid-November 2011), CRS and other diatoms dominated the calculated POC fluxes, with respectively 25.3 and $38.6 \%$. Diatoms other than spores dominated the calculated carbon flux (35.4\%) together with cylindrical faecal pellets $(36.4 \%)$ in cup \#2 (November 2011). TRS dominated the POC fluxes $(85.1 \%$ ) in cup \#3 (November/December 2011). CRS strictly dominated the calculated POC fluxes in summer (cups \#4 to \#10, December 2011 to February 2012), with a contribution ranging from 46.8 to $88.1 \%$. During the autumn and winter (cups \#11 and \#12, February to September 2012), POC fluxes were almost exclusively associated with tabular faecal pellets, 81 and $93.3 \%$, respectively. At annual scale, diatom's resting spores (CRS and TRS), other diatoms and faecal pellets respectively ac-

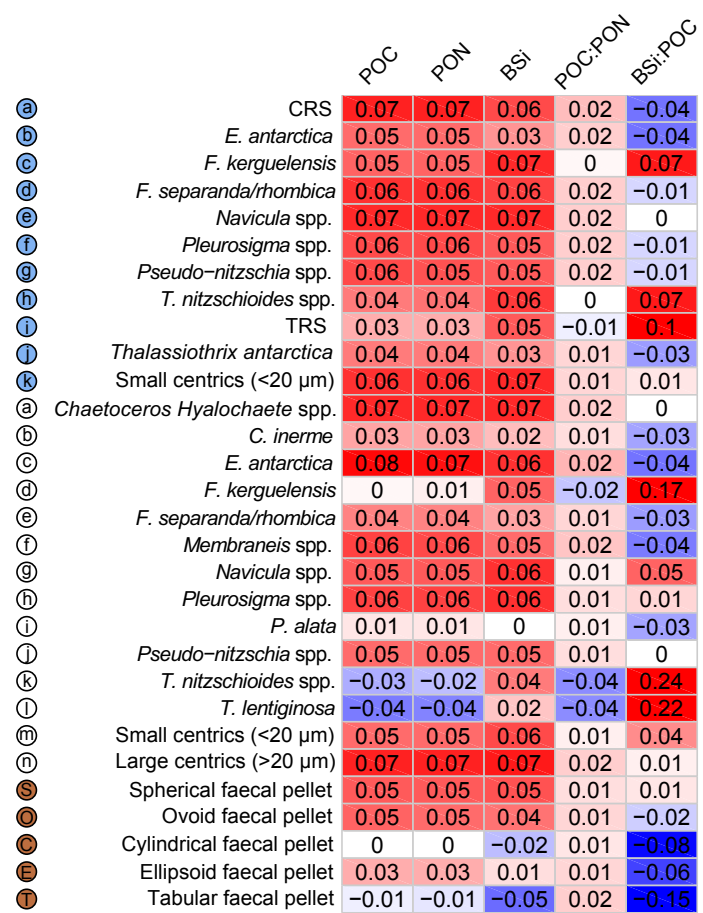

Figure 6. Heat map representation of $\beta$ correlation coefficients between the biological variables (empty and full cell diatom and faecal pellet type fluxes) and the chemical variables (POC, PON, BSi, POC : PON and BSi : POC) resulting from the partial least-squares regression. Blue circles represent full diatom cells, and white circles are empty diatom cells. Brown circles represent the faecal pellet type fluxes. The alphabetical labels within the circles are used to identify the variable projections shown in Fig. 7. CRS: Chaetoceros Hyalochaete resting spores; TRS: Thalassiosira antarctica resting spores.

counted for $60.7,5$ and $34.3 \%$ of the calculated POC fluxes. Annual POC fluxes estimated from ecological vectors considered here were slightly less than measured values ( 93.1 versus $98.2 \mathrm{mmol} \mathrm{m}^{-2}$ ).

\section{Discussion}

\subsection{The significance of resting spores for POC flux}

Generally POC fluxes were $<0.5 \mathrm{mmol} \mathrm{m}^{-2} \mathrm{~d}^{-1}$, with the notable exception of two pulsed ( $<14$ days) export events of $\sim 1.5 \mathrm{mmol} \mathrm{m}^{-2} \mathrm{~d}^{-1}$ that accounted for $\sim 40 \%$ of annual POC export. These two flux events were characterized by a noticeable increase and general dominance of diatom resting spores. During both of these pulsed export events, cumulative Chaetoceros Hyalochaete spp. resting spore (CRS and Thalassiosira antarctica resting spore (TRS) fluxes accounted for 66 and $88 \%$ of the measured POC flux, whereas total faecal pellet flux accounted for 29 and $5.2 \%$, respectively (Table 7). The combination of CRS and TRS was responsible for 
Table 7. Measured and calculated POC fluxes as well as POC flux partitioning among the major identified ecological vectors of carbon exported out of the mixed layer at station A3.

\begin{tabular}{|c|c|c|c|c|c|c|c|c|c|c|c|}
\hline \multirow[b]{2}{*}{ Cup } & \multirow[b]{2}{*}{$\begin{array}{c}\text { Measured POC } \\
\text { flux }\left(\mathrm{mmol} \mathrm{m}^{-2} \mathrm{~d}^{-1}\right)^{\mathrm{a}}\end{array}$} & \multirow[b]{2}{*}{$\begin{array}{c}\text { Calculated POC } \\
\text { flux }\left(\mathrm{mmol} \mathrm{m} \mathrm{m}^{-2} \mathrm{~d}^{-1}\right)\end{array}$} & \multicolumn{9}{|c|}{ Contribution to calculated POC flux (\%) } \\
\hline & & & $\mathrm{CRS}^{\mathrm{b}}$ & $\mathrm{TRS}^{\mathrm{c}}$ & $\begin{array}{r}\text { Other } \\
\text { diatoms }\end{array}$ & $\begin{array}{r}\text { Spherical } \\
\text { faecal pellet }\end{array}$ & $\begin{array}{r}\text { Ovoid faecal } \\
\text { pellet }\end{array}$ & $\begin{array}{r}\text { Cylindrical } \\
\text { faecal pellet }\end{array}$ & $\begin{array}{r}\text { Ellipsoid } \\
\text { faecal pellet }\end{array}$ & $\begin{array}{r}\text { Tabular } \\
\text { faecal pellet }\end{array}$ & $\begin{array}{r}\text { Total } \\
\text { faecal pellet }\end{array}$ \\
\hline 1 & 0.15 & 0.05 & 25.3 & 8.1 & 38.6 & 10.3 & 5.2 & 12.5 & 0.0 & 0.0 & 28.0 \\
\hline 2 & 0.14 & 0.06 & 0.0 & 0.0 & 35.4 & 14.5 & 13.7 & 36.4 & 0.0 & 0.0 & 64.6 \\
\hline 3 & 0.15 & 0.31 & 12.1 & 85.1 & 1.4 & 0.8 & 0.6 & 0.0 & 0.0 & 0.0 & 1.4 \\
\hline 4 & 1.60 & 1.62 & 46.8 & 19.4 & 3.9 & 24.8 & 4.6 & 0.5 & 0.0 & 0.0 & 29.8 \\
\hline 5 & 0.34 & 0.29 & 48.0 & 6.9 & 3.3 & 5.8 & 7.7 & 28.2 & 0.2 & 0.0 & 41.8 \\
\hline 6 & 0.51 & 0.63 & 69.7 & 2.7 & 3.2 & 1.1 & 2.7 & 10.5 & 0.0 & 10.1 & 24.4 \\
\hline 7 & 0.42 & 0.43 & 63.1 & 3.5 & 5.8 & 0.7 & 4.4 & 15.4 & 7.0 & 0.0 & 27.5 \\
\hline 8 & 0.34 & 0.56 & 54.4 & 2.9 & 6.8 & 0.7 & 0.8 & 12.4 & 5.7 & 16.3 & 35.9 \\
\hline 9 & 1.47 & 1.71 & 86.8 & 0.8 & 7.2 & 0.1 & 0.3 & 1.4 & 3.3 & 0.0 & 5.2 \\
\hline 10 & 0.55 & 0.44 & 88.1 & 0.0 & 4.3 & 1.4 & 0.7 & 5.4 & 0.3 & 0.0 & 7.7 \\
\hline 11 & 0.27 & 0.14 & 9.1 & 1.2 & 2.2 & 0.3 & 0.6 & 2.2 & 3.4 & 81.0 & 87.5 \\
\hline 12 & 0.04 & 0.06 & 0.0 & 0.0 & 0.5 & 0.4 & 2.6 & 5.2 & 0.0 & 91.3 & 99.5 \\
\hline \multicolumn{3}{|c|}{ Contribution to annual calculated POC flux (\% } & 52.1 & 8.6 & 5.0 & 5.1 & 2.0 & 5.2 & 2.2 & 19.8 & 34.3 \\
\hline
\end{tabular}

${ }^{a}$ Data from Rembauville et al. (2015). ${ }^{\mathrm{b}}$ CRS: Chaetoceros Hyalochaete resting spores. ${ }^{\mathrm{c}}$ TRS: Thalassiosira antarctica resting spores.

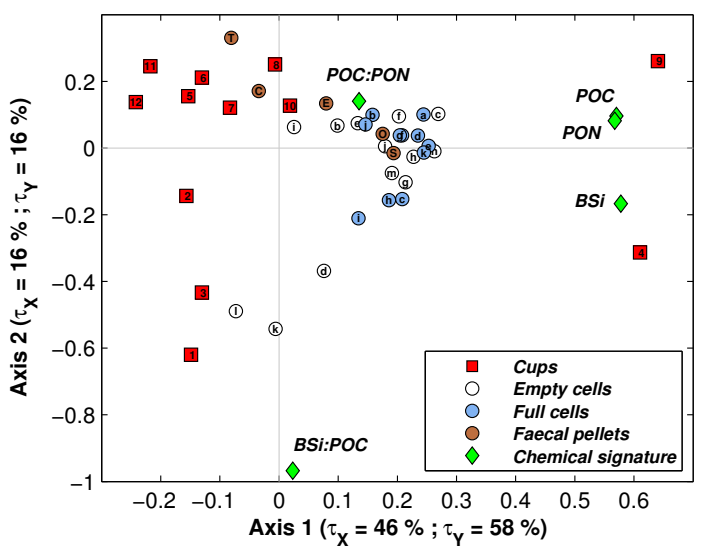

Figure 7. Projection of the cups (red squares), the biological factors (circles) and the chemical factors (green diamonds) in the first two latent vectors of the partial least-squares regression. Circled labels refer to the full and empty species listed in Fig. 6.

$60.7 \%$ of the annual calculated POC flux, a value 10 times higher than the contribution of other diatoms $(5 \%)$. We did not observe any full cells of the vegetative stage of Chaetoceros Hyalochaete, a feature possibly related to its high susceptibility to grazing pressure in the mixed layer (Smetacek et al., 2004; Quéguiner, 2013; Assmy et al., 2013). Empty Chaetoceros Hyalochaete spp. cells were vegetative stages different in shape from the resting spores. These empty frustules may be the remnants of vegetative stages following spore formation. Alternatively, dissolution of the lightly silicified valves or girdle bands of the vegetative cell could result in the rapid consumption of the cellular organic material in the upper water column, and this may also explain the absence of full vegetative cells in the sediment trap record. Our flux data reveal that small (10 to $30 \mu \mathrm{m})$ and highly silicified resting spores bypass the intense grazing pressure characterizing the base of the mixed layer, and are the primary mech- anism through which carbon, and to a lesser extent silicon, is exported from the surface.

Numerous sediment trap studies have reported a strong contribution, if not dominance, of CRS to diatom fluxes at depth in various oceanographic regions: firstly, in coastally influenced regions, e.g. the Antarctic Peninsula (Leventer, 1991), Bransfield Strait (Abelmann and Gersonde, 1991), Gulf of California (Sancetta, 1995), the Omura Bay (Kato et al., 2003), Santa Barbara basin (Lange, 1997), North Pacific Ocean (Chang et al., 2013) and the Artic (Onodera et al., 2015); secondly in upwelling-influenced regions (eastern equatorial Atlantic (Treppke et al., 1996); and finally in the open ocean in the subarctic Atlantic (Rynearson et al., 2013). Similar to sediment trap observations, CRS are reported as dominant in surface sediments of coastal regions (peri-Antarctic shelf and Antarctic sea ice (Crosta et al., 1997; Zielinski and Gersonde, 1997; Armand et al., 2005), the North Scotia Sea (Allen et al., 2005) and east of the Kerguelen Islands (Armand et al., 2008b), as well as in upwelling-influenced regions (e.g. the northeast Pacific; Grimm et al., 1996; Lopes et al., 2006) and finally in the open ocean (the North Atlantic; Bao et al., 2000). Moreover, the annual POC export from the A3 station sediment trap at $289 \mathrm{~m}\left(98.2 \pm 4.4 \mathrm{mmol} \mathrm{m}^{-2} \mathrm{yr}^{-1}\right)$ falls near annual estimates from deep sediment traps $(>2000 \mathrm{~m})$ located in the naturally fertilized area downstream of the Crozet Islands (37-60 and 40-42 $\mathrm{mmol} \mathrm{m}^{-2} \mathrm{yr}^{-1}$; Salter et al., 2012), where fluxes were considered as mainly driven by resting spores of Eucampia antarctica var. antarctica. Diatom resting spores are frequently observed in blooms heavily influenced by the proximity of the coast. Major resting spores' contribution to carbon fluxes was observed in only one study in the open North Atlantic Ocean (Rynearson et al., 2013), but they are generally absent or very rare in open ocean sediment trap studies (Fischer et al., 2002; Grigorov et al., 2014; Rigual-Hernández et al., 2015). The frequent occurrence and 

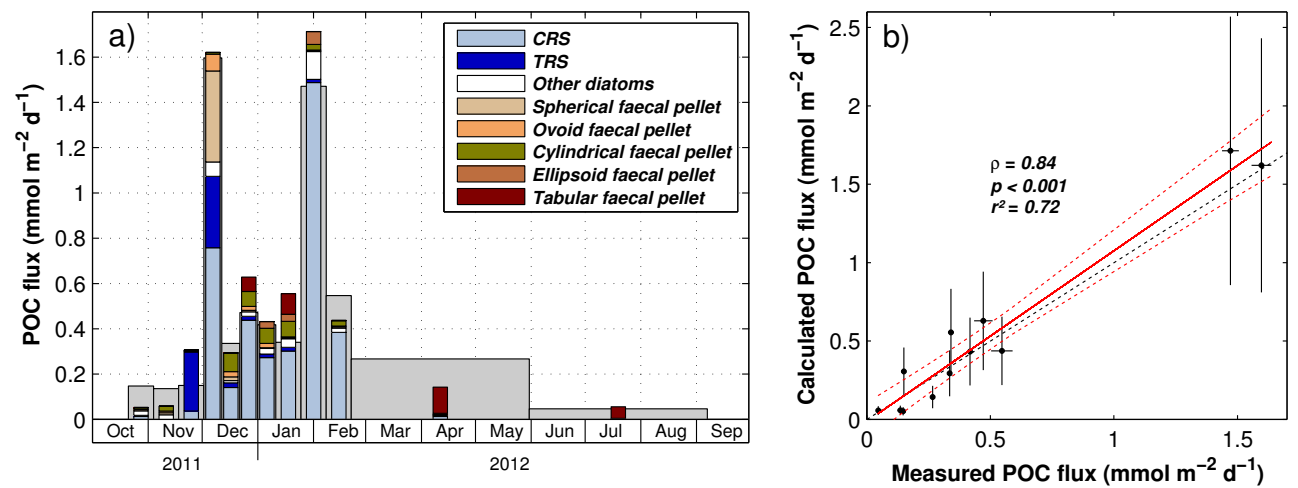

Figure 8. (a) Grey bars in the background are measured POC fluxes, and coloured bars in the foreground are calculated POC fluxes partitioned among the main ecological vectors identified. (b) Regression $\left(r^{2}=0.72\right)$ between the measured and calculated POC fluxes. The correlation is highly significant (Spearman rank correlation, $n=36, \rho=0.84, p<0.001$ ). Error bars were generated by increasing/decreasing the carbon/volume conversion factors by $50 \%$. Black dashed line is the $1: 1$ relation, red line is the regression line, and red dashed lines denotes the $99 \%$ confidence interval. CRS Chaetoceros Hyalochaete resting spores; TRS: Thalassiosira antarctica resting spores.

widespread distribution of a diatom's resting spores in the neritic or coastally influenced ocean suggest their pivotal role in the efficient transfer of carbon to depth in these areas.

Chaetoceros resting spores have been reported to contain up to 10 times more carbon than the vegetative forms (Kuwata et al., 1993) with no vacuole and high contents of lipids and carbohydrates (Doucette and Fryxell, 1983; Kuwata et al., 1993). Moreover, CRS resist grazing and have been found to lower copepods grazing pressure (Kuwata and Tsuda, 2005). We suggest that diatom resting spores gather three essential characteristics for effective POC export to the deep ocean: (1) they efficiently bypass the grazing pressure near the mixed layer due to their morphological characteristics such as very robust frustules (CRS) or numerous spines (TRS; high export efficiency), (2) they are efficiently transferred to depth due to the thick and dense frustule increasing sinking velocity and (3) their high carbon content is protected from microbial degradation by the thick frustules (these last two points result in a high transfer efficiency). The spatial distribution and formation of resting spores may therefore be an integral ecological component defining the strength and efficiency of the biological pump in specific regions. Nutrient depletion has been shown to trigger resting spore formation in Chaetoceros Hyalochaete laboratory cultures (Garrison, 1981; Sanders and Cibik, 1985; Kuwata et al., 1993; Oku and Kamatani, 1997) over relatively rapid timescales (6 to $48 \mathrm{~h}$; McQuoid and Hobson, 1996). Although $\mathrm{Si}(\mathrm{OH})_{4}$ depletion appears to be the most likely biogeochemical trigger at the Kerguelen Plateau (from $24 \mu \mathrm{mol} \mathrm{L}{ }^{-1}$ in early spring to $2 \mu \mathrm{mol} \mathrm{L}^{-1}$ in summer (Mosseri et al., 2008; Closset et al., 2014), other environmental factors (iron or light availability) could influence resting spore formation. Notably, dissolved iron concentration in the mixed layer rapidly decreases to $\sim 0.1$ to $0.2 \mathrm{nmol} \mathrm{L}^{-1}$ after the beginning of the spring bloom at A3; however the vertical entrainment is much weaker in summer compared to spring (Bowie et al., 2014). Rynearson et al. (2013) reported the absence of spores in the mixed layer despite a strict dominance of the trap samples. Resting spore formation at some depth below the summer mixed layer (possibly implying a light control) could explain the temporal decoupling between the surface production tracked by the satellite in the surface layer (first $\sim 20 \mathrm{~m}$ ) and the export events. Further work to establish seasonal dynamics of factors linked to diatom life cycles and specifically the formation of resting spores is necessary.

\subsection{Contribution of faecal pellets to POC flux}

Although diatom resting spores are the primary vector for POC flux below the mixed layer, faecal pellets were also important and accounted for $34.3 \%$ of annual export. It has been hypothesized that faecal pellets are the dominant flux component in high-biomass, low-export (HBLE) environments, where biomass is routed to higher trophic levels (Lam and Bishop, 2007; Ebersbach et al., 2011). However, this hypothesis does not appear to be true for the bloom of the central Kerguelen Plateau, suggesting that faecal material is efficiently reprocessed in the mixed layer, or that a significant part of the pellet flux is excreted below the trap depth by vertically migrating zooplankton. Small spherical faecal pellets dominated the annual numerical faecal pellet flux $(53.8 \%$, Table 6). The short and intense export of small spherical faecal pellets was concomitant with the first strong POC export in cup \#4 (December 2011, Table 6). The significance of small spherical faecal pellets to POC flux is somewhat uncharacteristic in comparison to other sediment trap records in shallow areas of the Southern Ocean (Schnack-Schiel and Isla, 2005). They are possibly produced by small cyclopoid copepods, like Oithona similis, that are abundant in the POOZ (Fransz and Gonzalez, 1995; Pinkerton et al., 2010). More specifically, $O$. similis represents $>50 \%$ of mesozoo- 
plankton abundance at A3 in spring (Carlotti et al., 2015) and has been observed at station A3 in summer (Carlotti et al., 2008). Oithona species are known to be coprophagous and play an important role in flux reprocessing (Gonzalez and Smetacek, 1994), which may partially contribute to the rapid flux attenuation observed by efficiently retaining carbon in the mixed layer. This reprocessing feeding strategy might also explain the low faecal pellet flux we observed (highest value of $21.8 \times 10^{3}$ pellet $\mathrm{m}^{-2} \mathrm{~d}^{-1}$ ), which was 2 orders of magnitude lower than the $>5 \times 10^{5}$ pellet $\mathrm{m}^{-2} \mathrm{~d}^{-1}$ observed in neritic areas where euphausiids dominate the mesozooplankton community (von Bodungen, 1986; von Bodungen et al., 1987; Wefer et al., 1988).

There were notable differences in faecal pellet types over the course of the season. The transition from spherical and ovoid pellets in spring to larger cylindrical and tabular pellets in summer presumably reflects shifts in dominant zooplankton species from small cyclopoid copepods towards larger calanoid copepods, euphausiids and salps (e.g. Wilson et al., 2013). Carlotti et al. (2015) report that mesozooplankton biomass doubled between October and November 2011 and was 3-fold higher in January 2005 (Carlotti et al., 2008). In spring, Carlotti et al. (2015) observed that the small size fraction $(300-500 \mu \mathrm{m})$ was numerically dominated by Oithona similis (50\% of the total mesozooplankton assemblage), although the larger size fractions dominated the mesozooplankton biomass (dominated by Clausocalanus citer and Rhicalanus gigas). This is consistent with the dominance of small spherical faecal pellets and the lower contribution of cylindrical shapes we observed in spring and early summer (cups \#1 to \#4, October to December 2011, Table 6). In summer (January 2005), the mesozooplankton community was more diversified and comprised $21 \%$ small individuals (Oithona sp. and Oncea sp.), $20 \%$ medium-sized individuals (Clausocalanus sp. and Microcalanus sp.) and $21 \%$ large individuals (Calanus sp., Metrida sp., Paraeuchaeta sp., Pleuromamma sp. and Rhincalanus sp.; Carlotti et al., 2008). As the median size of faecal pellets increases, so does their relative contribution to carbon flux (Fig. 5b and d, Table 6). Our observation of an increasing contribution of cylindrical faecal pellet shapes in summer (cups \#5 to \#10, December 2011 to February 2012, Table 6) is consistent with the increasing contribution of large calanoid copepods to the mesozooplankton assemblages. We note that pteropods showed the highest contribution to mesozooplankton assemblages at station A3 in summer (16\% of total abundance; Carlotti et al., 2008). We associate this observation with the large ellipsoid faecal pellet shape that was first observed in the sediment trap in cup \#5 (end of December 2011) and represented the highest contribution to faecal pellet carbon fluxes in cup \#9 (January/February 2012, Table 7). Tabular faecal pellets dominated the low POC fluxes observed in the autumn and winter, when chlorophyll $a$ concentration was reduced to background levels, although this interpretation should be treated with caution since a constant and high carbon con- tent was used for this shape. The increase in organic carbon content and negative correlation between the abundance of cylindrical, ellipsoid and tabular faecal pellets fluxes and the $\mathrm{BSi}$ : POC molar ratio suggests that large zooplankton producing these tabular pellets (large copepods, euphausiids and salps) was not feeding directly on diatoms. During the autumn and winter, microbial components other than diatoms must sustain the production of these large zooplankton. Direct observation of faecal pellet content is beyond the scope of the present study but would help in elucidating how seasonal trends of zooplankton feeding ecology influence carbon and biomineral export. Moreover, dedicated studies are still needed to document the seasonal dynamic of euphausiid and salp abundances over the Kerguelen Plateau to compare them with our reported faecal pellet fluxes.

\subsection{Diatom fluxes}

The diatom fluxes (sum of empty and full cells) observed at the central Kerguelen Plateau reached their maximum value of $1.2 \times 10^{8}$ cells m$^{-2} \mathrm{~d}^{-1}$ during the two short export events, which is equivalent to $2.4 \times 10^{8}$ valves $\mathrm{m}^{-2} \mathrm{~d}^{-1}$. This latter value falls between the highest values observed in POOZ $\left(\sim 10^{7}\right.$ valves $\mathrm{m}^{-2} \mathrm{~d}^{-1}$; Abelmann and Gersonde, 1991; Salter et al., 2012; Grigorov et al., 2014) and the SIZ (> $10^{9}$ valves $\mathrm{m}^{-2} \mathrm{~d}^{-1}$; Suzuki et al., 2001; Pilskaln et al., 2004). The diatom fluxes over the Kerguelen Plateau are similar to the $2.5-3.5 \times 10^{8}$ valves $\mathrm{m}^{-2} \mathrm{~d}^{-1}$ measured at $200 \mathrm{~m}$ depth in a coastal station of the Antarctic Peninsula, where CRS represented $\sim 80 \%$ of the phytoplankton assemblage (Leventer, 1991). Previous studies report the presence of a resting spore formation strategy in diatom species as typically associated with neritic areas (Smetacek, 1985; Crosta et al., 1997; Salter et al., 2012). During the summer KEOPS1 cruise, a shift in plankton community composition was observed at station A3 between January and February. The surface community initially dominated by Chaetoceros Hyalochaete vegetative chains gave way to one dominated by Eucampia antarctica var. antarctica, concomitant with increasing CRS abundance in the mixed layer (Armand et al., 2008a). The abundance of dead cells (within chains or as empty single cells and half-cells) in the surface water column also increased from January to February, suggesting intense heterotrophic activity. Surface sediments at station A3 contain, in decreasing abundance, F. kerguelensis, CRS and T. nitzschioides spp. cells (Armand et al., 2008b). These sedimentary distributions are consistent with the dominant species observed in the sediment trap, F. kerguelensis and T. nitzschioides spp. being present throughout the year and mostly represented by empty cells, whereas CRS are exported during short and intense events.

Eucampia antarctica var. antarctica resting spores dominated the deep $(2000 \mathrm{~m})$ sediment trap diatom assemblages in the naturally fertilized area close to the Crozet Islands with fluxes $>10^{7}$ cells $\mathrm{m}^{-2} \mathrm{~d}^{-1}$ (Salter et al., 2012). We ob- 
served highest Eucampia antarctica var. antarctica full cell fluxes of $\sim 10^{6}$ cells $\mathrm{m}^{-2} \mathrm{~d}^{-1}$ in summer, which represents $<10 \%$ of the total cell flux. Both vegetative and resting stages were observed. Our results suggest that Eucampia antarctica var. antarctica are unlikely to be a major driving vector for carbon fluxes to depth over the central Kerguelen Plateau, in part because the community was not forming massive highly silicified, fast-sinking resting spores, contrary to observations near the Crozet Islands. Moreover their biogeographic abundance distribution from sea floor observations suggests they are not dominant in this region of the plateau (Armand et al., 2008b). The iron-fertilized Crozet bloom is north of the polar front and dissolved $\mathrm{Si}(\mathrm{OH})_{4}$ concentrations were depleted to $0.2 \mu \mathrm{mol} \mathrm{L}^{-1}$ (Salter et al., 2007) compared to $\sim 2 \mu \mathrm{mol} \mathrm{L}^{-1}$ on the Kerguelen Plateau (Mosseri et al., 2008). It is possible, along with differences in iron dynamics between the two plateaus, that differences in nutrient stoichiometry favour bloom dynamics and resting spore formation of Chaetoceros Hyalochaete populations surrounding the Kerguelen Islands. Nevertheless, the increasing full cell flux of Eucampia antarctica var. antarctica from spring to summer in the sediment trap time series is consistent with the observations of an increasing abundance in the mixed layer at the station A3 in summer (Armand et al., 2008a).

Highest Pseudo-nitzschia spp. full cell fluxes were observed in summer, concomitantly with the second export peak (cup \#9, end of January 2012). Pseudo-nitzschia species are rarely found in deep sediment trap studies and are absent from sediment diatom assemblages, presumably due to their susceptibility to water column dissolution (Grigorov et al., 2014; Rigual-Hernández et al., 2015). The species Pseudonitzschia hemii has been reported to accumulate in summer in deep chlorophyll maximum in the Polar Frontal Zone (Kopczynska et al., 2001). Such deep biomass accumulation is hypothesized to benefit from nutrient diffusion through the pycnocline (Parslow et al., 2001). These general observations are consistent with the peaks in Pseudo-nitzschia spp. fluxes we report in summer over the Kerguelen Plateau.

Although their fluxes were very low, species of the Rhizosolenia and Proboscia genera were mostly exported as empty cells at the end of summer and during autumn (cups \#8 to \#11, end of January to May 2012), occurring in parallel with the full cell fluxes of the giant diatom Thalassiothrix antarctica (Table 4). It has been suggested that these species belong to a group of "deep shade flora" that accumulate at the subsurface chlorophyll maxima in summer, with their large frustules protecting them from grazing pressure in stratified waters (Kemp and Villareal, 2013). Interestingly these species were also found in deep sediment traps located in an HNLC area south of the Crozet Plateau (Salter et al., 2012), as well as in subsurface chlorophyll maximum in HNLC waters of the Southern Ocean (Parslow et al., 2001; Holm-Hansen et al., 2004; Gomi et al., 2010). A subsurface chlorophyll maximum has previously been observed at $120 \mathrm{~m}$ on the Kerguelen Plateau (also station A3) during summer
(Uitz et al., 2009) and appears to correspond to an accumulation of particles consisting of aggregates of large diatom species (Jouandet et al., 2011). The fact that Rhizosolenia spp. and Proboscia spp. were observed as empty cells whereas Thalassiothrix antarctica was mostly represented by full cells suggests species-specific grazing on these communities. There appears to be ecological differentiation within the "deep shade flora" that precludes describing a single effect on export stoichiometry. Moreover, on the Kerguelen Plateau, these species are not exported in "massive" proportions as the "fall-dump" hypothesis suggests (Kemp et al., 2000). The physical and biogeochemical factors responsible for their production and export are still to be determined, and should be investigated thoroughly given the potential importance that these species might have for export fluxes on a global scale (Kemp et al., 2000; Richardson et al., 2000; Kemp and Villareal, 2013).

\subsection{Preferential carbon and silica sinkers}

Unlike most previous sediment trap studies in the Southern Ocean, we used a counting technique that facilitated the identification of carbon and siliceous components of exported material. Although we lost a small degree of taxonomic resolution with this approach (see Methods), it allowed us to avoid unnecessary assumptions concerning carbon content of exported diatoms and directly constrain the role of different species for carbon and silica export.

The annual BSi : POC ratio of the exported material (1.16) is much higher than the usual ratio proposed for marine diatoms of 0.13 (Brzezinski, 1985). Moreover, the BSi : POC ratio of the exported material in spring (2.1 to 3.4, cups \#1 to \#3, October to mid-December 2011) is significantly higher than the BSi:POC ratio of 0.3 to 0.7 in the mixed layer of the same station during spring (Lasbleiz et al., 2014; Trull et al., 2015). Numerous chemical, physical, biological and ecological factors can impact BSi : POC ratios of marine diatoms (e.g. Ragueneau et al., 2006). However, the 10-fold differences in BSi : POC ratios of exported particles between spring and summer is unlikely to result only from physiological constraints set during diatoms growth (Hutchins and Bruland, 1998; Takeda, 1998). Previous comparisons in natural and artificially iron-fertilized settings have highlighted the importance of diatom community structure for carbon and silica export (Smetacek et al., 2004; Salter et al., 2012; Quéguiner, 2013; Assmy et al., 2013). The presence of different diatom species and their characteristic traits (e.g. susceptibility to grazing, apoptosis, viral lysis) are all likely to influence the flux of full and empty cells. Therefore, the net BSi : POC export ratio results from the net effect of species-specific Si : C composition (Sackett et al., 2014) and the subsequent species-specific mortality pathway and dissolution. A significant correlation between BSi : POC and empty: full cell ratio (Spearman rank correlation, $n=12$, $\rho=0.78, p<0.05$ ) suggests the latter acts as a first-order 
control on the silicon and organic carbon export stoichiometry. Differences in BSi : POC ratios between the mixed layer suspended particle stock and particles exported out of the mixed layer may be explained by the dominant sedimentation of empty diatom frustules that results from the grazing pressure by the zooplankton community and the intense carbon utilization by heterotrophic microbial communities (Christaki et al., 2014).

We classified species that were observed exclusively as empty cells, or sinking with an integrated empty: full ratio $>2$, as predominantly silica exporters, and these included $C$. bulbosus, $C$. pennatum, $P$. truncata, $R$. antennata/styliformis, A. hookeri, A. hyalinus, $C$. decipiens, $C$. inerme, D. antarcticus, P. alata, T. nitzschioides spp., T. lentiginosa and small centric species $(<20 \mu \mathrm{m})$. Although $F$. kerguelensis, T. nitzschioides spp. and T. lentiginosa were present through the entire season, their fluxes were highly correlated with $\mathrm{BSi}$ : $\mathrm{POC}$ ratios (Fig. 6), identifying these species as significant contributors to silica export. However, resting spores and species that sink with a major contribution of full cells (integrated empty: full ratio <0.5) were identified as belonging to the preferential carbon sinkers: Chaetoceros Hyalochaete spp., E. antarctica var. antarctica, R. simplex and Thalassiothrix antarctica. Among them, CRS and E. antarctica var. antarctica were the most negatively correlated with the $\mathrm{BSi}$ : $\mathrm{POC}$ ratio and were identified as key species for carbon export (Fig. 6). These observations are consistent with a previous study of natural iron fertilization that identified C. pennatum, D. antarcticus and F. kerguelensis as major silica sinkers and CRS and E. antarctica var. antarctica resting spores as major carbon sinkers downstream of the Crozet Islands (Salter et al., 2012). During the EIFEX artificial fertilization experiment, Chaetoceros Hyalochaete vegetative stages were identified as a major carbon sinker, whereas $F$. kerguelensis was considered as a strong silica sinker (Assmy et al., 2013). Notably, resting spore formation was not observed in the artificial experiment performed in the open ocean remote from coastal influence, and carbon export was attributed to mass mortality and aggregation of algal cells (Assmy et al., 2013). Nevertheless, a more detailed analysis of species-specific carbon and silica content in the exported material is necessary to fully elucidate their respective roles on carbon and silica export.

\subsection{Seasonal succession of ecological flux vectors over the Kerguelen Plateau}

Although sediment trap records integrate cumulative processes of production in the mixed layer and selective losses during export, they provide a unique insight into the temporal succession of plankton functional types and resultant geochemical properties of exported particles characterizing the biological pump. The seasonal cycle of ecological vectors and associated export stoichiometry is summarized in Fig. 7. The robustness of the relationship between measured and calculated POC fluxes (Fig. 8b) suggests that the main ecological flux vectors described from the samples are capable of predicting seasonal patterns of total POC fluxes. At an annual scale the calculated POC fluxes slightly underestimate the measured fluxes ( 93.1 vs. $98.2 \mathrm{mmol} \mathrm{m}^{-2}$ ). This might result from the minor contribution of full cells other than the diatoms species considered, aggregated material, organic matter sorbed to the exterior of empty cells and faecal fluff that was difficult to enumerate.

A scheme of phytoplankton and zooplankton communities succession in naturally fertilized areas of the Southern Ocean was proposed by Quéguiner (2013). Spring phytoplankton communities are characterized by small, lightly silicified, fast-growing diatoms associated with small microphagous copepods. In summer, the phytoplankton community progressively switches toward large, highly silicified, slow-growing diatoms resistant to grazing by large copepods. In this scheme carbon export occurs mostly in the end of summer through the fall dump. The species succession directly observed in our sediment trap samples differs somewhat to the conceptual model proposed by Quéguiner (2013), although the general patterns are similar. The diatom species exported in spring were $F$. kerguelensis and $T$. nitzschioides spp. and small centric species $(<20 \mu \mathrm{m})$, whilst in summer the comparatively very large ( $>200 \mu \mathrm{m})$ species of Proboscia sp., Rhizosolenia sp. and Thalassiothrix antarctica were observed. However we observe that these species constituting the spring fluxes are exported almost exclusively as empty cells. The abundance of small spherical and ovoid faecal pellet suggests an important role of small copepods in the zooplankton (Yoon et al., 2001; Wilson et al., 2013), which was corroborated by the finding of dominant Oithona similis abundances in the spring mesozooplankton assemblages at station A3 (Carlotti et al., 2015). Therefore, our data suggest that spring export captured by the sediment trap was the remnants of a diatom community subject to efficient grazing and carbon utilization in, or at the base of, the mixed layer, resulting in a BSi: $\mathrm{POC}$ export ratio > 2 (Table 1).

The main difference in our observations and the conceptual scheme of Quéguiner (2013) is the dominance of Chaetoceros Hyalochaete resting spores to diatom export assemblages and their contribution to carbon fluxes out of the mixed layer in summer. Resting spores appear to efficiently bypass the "carbon trap" represented by grazers and might also physically entrain small faecal pellets in their downward flux. In mid-summer, faecal pellet carbon export is dominated by the contribution of cylindrical shapes. This appears to be consistent with an observed shift toward a higher contribution of large copepods and euphausiids to the mesozooplankton community in the mixed layer (Carlotti et al., 2008). However, CRS still dominate the diatom exported assemblage. The corresponding BSi : POC ratio decreases with values between 1 and 2 (Table 1). The fact that there are two discrete resting spore export events might be explained by a 
mixing event that injected $\mathrm{Si}(\mathrm{OH})_{4}$ into the surface, allowing the development of a secondary $\mathrm{Si}(\mathrm{OH})_{4}$ limitation.

In the autumn and winter, diatom fluxes are very low and faecal pellet carbon export is dominated by cylindrical and tabular contributions consistent with a supposed shift to zooplankton communities dominated by large copepods, euphausiids and salps (Wilson et al., 2013). The low BSi : POC ratios characterizing export at this time suggest that these communities feed primarily on suspended particles (in the case of salps) and on micro- and mesozooplankton or small diatoms, although direct measurements of faecal pellet content would be necessary to confirm this.

\section{Conclusions}

We report the chemical (particulate organic carbon and nitrogen, biogenic silica) and biological (diatom cells and faecal pellets) composition of material exported beneath the winter mixed layer $(289 \mathrm{~m})$ in a naturally iron-fertilized area of the Southern Ocean. Annually integrated organic carbon export from the iron-fertilized bloom was low $\left(98 \mathrm{mmol} \mathrm{m}^{-2}\right)$, although biogenic silicon export was significant $\left(114 \mathrm{mmol} \mathrm{m}^{-2}\right)$. Chaetoceros Hyalochaete and Thalassiosira antarctica resting spores accounted for more than $60 \%$ of the annual POC flux. The high abundance of empty cells and the lower contribution of faecal pellets to POC flux $(34 \%)$ suggest efficient carbon retention occurs in or at the base of the mixed layer. We propose that, in this HBLE environment, carbon-rich and fast-sinking resting spores bypass the intense grazing pressure otherwise responsible for the rapid attenuation of flux. The seasonal succession of diatom taxa groups was tightly linked to the stoichiometry of the exported material. Several species were identified as primarily "silica sinkers" (e.g. Fragilariopsis kerguelensis and Thalassionema nitzschioides spp.) and others as preferential "carbon sinkers" (e.g. resting spores of Chaetoceros Hyalochaete and Thalassiosira antarctica, Eucampia antarctica var. antarctica and the giant diatom Thalassiothrix antarctica). Faecal pellet types described a clear transition from small spherical shapes (small copepods) in spring, larger cylindrical an ellipsoid shapes in summer (euphausiids and large copepods) and large tabular shape (salps) in autumn. Their contribution to carbon fluxes increased with the presence of larger shapes.

The change in biological productivity and ocean circulation cannot explain the $\sim 80 \mathrm{ppmv}$ atmospheric $p \mathrm{CO}_{2}$ difference between the pre-industrial era and the Last Glacial Maximum (Archer et al., 2000; Bopp et al., 2003; Kohfeld et al., 2005; Wolff et al., 2006). Nevertheless, a simple switch in "silica sinker" versus "carbon sinker" relative abundance would have a drastic effect on carbon sequestration in the Southern Ocean and silicic acid availability at lower latitudes (Sarmiento et al., 2004; Boyd, 2013). The results presented here emphasize the compelling need for similar studies in other locations of the global Ocean that will allow for identification of key ecological vectors that set the magnitude and the stoichiometry of the biological pump.

\section{The Supplement related to this article is available online at doi:10.5194/bg-12-3171-2015-supplement.}

Acknowledgements. We thank Captain Bernard Lassiette and his crew during the KEOPS2 mission on the R/V Marion Dufresne II. We thank Karine Leblanc and Marine Lasbleiz and the three anonymous reviewers for their constructive comments, which helped us to improve the manuscript. This work was supported by the French Research programme of INSU-CNRS LEFE-CYBER (Les enveloppes fluides et l'environnement - Cycles biogéochimiques, environnement et ressources), the French ANR (Agence Nationale de la Recherche, SIMI-6 programme, ANR-10-BLAN-0614), the French CNES (Centre National d'Etudes Spatiales) and the French Polar Institute IPEV (Institut Polaire Paul-Emile Victor). L. Armand's participation in the KEOPS2 programme was supported by an Australian Antarctic Division grant (\#3214).

Edited by: T. Trull

\section{References}

Abdi, H.: Partial least squares regression and projection on latent structure regression (PLS Regression), Wiley Interdiscip. Rev. Comput. Stat., 2, 97-106, doi:10.1002/wics.51, 2010.

Abelmann, A. and Gersonde, R.: Biosiliceous particle flux in the Southern Ocean, Mar. Chem., 35, 503-536, doi:10.1016/S03044203(09)90040-8, 1991.

Allen, C. S., Pike, J., Pudsey, C. J., and Leventer, A.: Submillennial variations in ocean conditions during deglaciation based on diatom assemblages from the southwest Atlantic, Paleoceanography, 20, PA2012, doi:10.1029/2004PA001055, 2005.

Aminot, A. and Kerouel, R.: Dosage automatique des nutriments dans les eaux marines: methodes en flux continu, Ifremer, Plouzané, France, 2007.

Archer, D., Winguth, A., Lea, D., and Mahowald, N.: What caused the glacial/interglacial atmospheric $p \mathrm{CO}_{2}$ cycles?, Rev. Geophys., 38, 159-189, doi:10.1029/1999RG000066, 2000.

Armand, L. K., Crosta, X., Romero, O., and Pichon, J.-J.: The biogeography of major diatom taxa in Southern Ocean sediments: 1. Sea ice related species, Palaeogeogr. Palaeoecl., 223, 93-126, doi:10.1016/j.palaeo.2005.02.015, 2005.

Armand, L. K., Crosta, X., Quéguiner, B., Mosseri, J., and Garcia, N.: Diatoms preserved in surface sediments of the northeastern Kerguelen Plateau, Deep-Sea Res. Pt. II, 55, 677-692, doi:10.1016/j.dsr2.2007.12.032, 2008a.

Armand, L. K., Cornet-Barthaux, V., Mosseri, J., and Quéguiner, B.: Late summer diatom biomass and community structure on and around the naturally iron-fertilised Kerguelen Plateau in the Southern Ocean, Deep-Sea Res. Pt. II, 55, 653-676, doi:10.1016/j.dsr2.2007.12.031, 2008b. 
Arrigo, K. R., Worthen, D., Schnell, A., and Lizotte, M. P.: Primary production in Southern Ocean waters, J. Geophys. Res.-Oceans, 103, 15587-15600, doi:10.1029/98JC00930, 1998.

Assmy, P., Smetacek, V., Montresor, M., Klaas, C., Henjes, J., Strass, V. H., Arrieta, J. M., Bathmann, U., Berg, G. M., Breitbarth, E., Cisewski, B., Friedrichs, L., Fuchs, N., Herndl, G. J., Jansen, S., Krägefsky, S., Latasa, M., Peeken, I., Röttgers, R., Scharek, R., Schüller, S. E., Steigenberger, S., Webb, A., and Wolf-Gladrow, D.: Thick-shelled, grazer-protected diatoms decouple ocean carbon and silicon cycles in the iron-limited Antarctic Circumpolar Current, P. Natl. Acad. Sci., 110, 2063320638, doi:10.1073/pnas.1309345110, 2013.

Baker, E. T., Milburn, H. B., and Tennant, D. A.: Field assessment of sediment trap efficiency under varying flow conditions, J. Mar. Res., 46, 573-592, doi:10.1357/002224088785113522, 1988.

Bao, R., Stigter, H. D., and Weering, T. C. E. V.: Diatom fluxes in surface sediments of the Goban Spur continental margin, NE Atlantic Ocean, J. Micropalaeontol., 19, 123-131, doi:10.1144/jm.19.2.123, 2000.

Blain, S., Tréguer, P., Belviso, S., Bucciarelli, E., Denis, M., Desabre, S., Fiala, M., Martin Jézéquel, V., Le Fèvre, J., Mayzaud, P., Marty, J.-C., and Razouls, S.: A biogeochemical study of the island mass effect in the context of the iron hypothesis: Kerguelen Islands, Southern Ocean, Deep-Sea Res. Pt. I, 48, 163-187, doi:10.1016/S0967-0637(00)00047-9, 2001.

Blain, S., Quéguiner, B., Armand, L., Belviso, S., Bombled, B., Bopp, L., Bowie, A., Brunet, C., Brussaard, C., Carlotti, F., Christaki, U., Corbière, A., Durand, I., Ebersbach, F., Fuda, J.L., Garcia, N., Gerringa, L., Griffiths, B., Guigue, C., Guillerm, C., Jacquet, S., Jeandel, C., Laan, P., Lefèvre, D., Lo Monaco, C., Malits, A., Mosseri, J., Obernosterer, I., Park, Y.-H., Picheral, M., Pondaven, P., Remenyi, T., Sandroni, V., Sarthou, G., Savoye, N., Scouarnec, L., Souhaut, M., Thuiller, D., Timmermans, K., Trull, T., Uitz, J., van Beek, P., Veldhuis, M., Vincent, D., Viollier, E., Vong, L., and Wagener, T.: Effect of natural iron fertilization on carbon sequestration in the Southern Ocean, Nature, 446, 10701074, doi:10.1038/nature05700, 2007.

Blain, S., Renaut, S., Xing, X., Claustre, H., and Guinet, C.: Instrumented elephant seals reveal the seasonality in chlorophyll and light-mixing regime in the iron-fertilized Southern Ocean, Geophys. Res. Lett., 40, 6368-6372, doi:10.1002/2013GL058065, 2013.

Bopp, L., Kohfeld, K. E., Le Quéré, C., and Aumont, O.: Dust impact on marine biota and atmospheric $\mathrm{CO}_{2}$ during glacial periods, Paleoceanography, 18, 1046, doi:10.1029/2002PA000810, 2003.

Bowie, A. R., van der Merwe, P., Quéroué, F., Trull, T., Fourquez, M., Planchon, F., Sarthou, G., Chever, F., Townsend, A. T., Obernosterer, I., Sallée, J.-B., and Blain, S.: Iron budgets for three distinct biogeochemical sites around the Kerguelen archipelago (Southern Ocean) during the natural fertilisation experiment KEOPS-2, Biogeosciences Discuss., 11, 17861-17923, doi:10.5194/bgd-11-17861-2014, 2014.

Boyd, P. W.: Diatom traits regulate Southern Ocean silica leakage, P. Natl. Acad. Sci., 110, 20358-20359, doi:10.1073/pnas.1320327110, 2013.

Brzezinski, M. A.: The Si:C:N ratio of marine diatoms: interspecific variability and the effect of some environmental variables,
J. Phycol., 21, 347-357, doi:10.1111/j.0022-3646.1985.00347.x, 1985.

Brzezinski, M. A., Pride, C. J., Franck, V. M., Sigman, D. M., Sarmiento, J. L., Matsumoto, K., Gruber, N., Rau, G. H., and Coale, K. H.: A switch from $\mathrm{Si}(\mathrm{OH})_{4}$ to $\mathrm{NO}_{3}$ depletion in the glacial Southern Ocean, Geophys. Res. Lett., 29, 1564, doi:10.1029/2001GL014349, 2002.

Buesseler, K. O.: The decoupling of production and particulate export in the surface ocean, Glob. Biogeochem. Cy., 12, 297-310, doi:10.1029/97GB03366, 1998.

Buesseler, K. O., Steinberg, D. K., Michaels, A. F., Johnson, R. J., Andrews, J. E., Valdes, J. R., and Price, J. F.: A comparison of the quantity and composition of material caught in a neutrally buoyant versus surface-tethered sediment trap, Deep-Sea Res. Pt. I, 47, 277-294, doi:10.1016/S0967-0637(99)00056-4, 2000.

Buesseler, K. O., Antia, A. N., Chen, M., Fowler, S. W., Gardner, W. D., Gustafsson, Ö., Harada, K., Michaels, A. F., Rutgers v. d. Loeff, M., Sarin, M., Steinberg, D. K., and Trull, T.: An assessment of the use of sediment traps for estimating upper ocean particle fluxes, J. Mar. Res., 65, 345-416, 2007.

Burd, A. B. and Jackson, G. A.: Particle Aggregation, Annu. Rev. Mar. Sci., 1, 65-90, doi:10.1146/annurev.marine.010908.163904, 2009.

Carlotti, F., Thibault-Botha, D., Nowaczyk, A., and Lefèvre, D.: Zooplankton community structure, biomass and role in carbon fluxes during the second half of a phytoplankton bloom in the eastern sector of the Kerguelen Shelf (January-February 2005), Deep-Sea Res. Pt. II, 55, 720-733, doi:10.1016/j.dsr2.2007.12.010, 2008.

Carlotti, F., Jouandet, M.-P., Nowaczyk, A., Harmelin-Vivien, M., Lefèvre, D., Guillou, G., Zhu, Y., and Zhou, M.: Mesozooplankton structure and functioning during the onset of the Kerguelen phytoplankton bloom during the Keops2 survey, Biogeosciences Discuss., 12, 2381-2427, doi:10.5194/bgd-12-2381-2015, 2015.

Cavan, E. L., Le Moigne, F. A. C., Poulton, A. J., Tarling, G. A., Ward, P., Daniels, C. J., Fragoso, G., and Sanders, R. J.: Zooplankton fecal pellets control the attenuation of particulate organic carbon flux in the Scotia Sea, Southern Ocean, Geophys. Res. Lett., GL062744, doi:10.1002/2014GL062744, 2015.

Chang, A. S., Bertram, M. A., Ivanochko, T., Calvert, S. E., Dallimore, A., and Thomson, R. E.: Annual record of particle fluxes, geochemistry and diatoms in Effingham Inlet, British Columbia, Canada, and the impact of the 1999 La Niña event, Mar. Geol., 337, 20-34, doi:10.1016/j.margeo.2013.01.003, 2013.

Christaki, U., Lefèvre, D., Georges, C., Colombet, J., Catala, P., Courties, C., Sime-Ngando, T., Blain, S., and Obernosterer, I.: Microbial food web dynamics during spring phytoplankton blooms in the naturally iron-fertilized Kerguelen area (Southern Ocean), Biogeosciences, 11, 6739-6753, doi:10.5194/bg-116739-2014, 2014.

Closset, I., Lasbleiz, M., Leblanc, K., Quéguiner, B., Cavagna, A.J., Elskens, M., Navez, J., and Cardinal, D.: Seasonal evolution of net and regenerated silica production around a natural $\mathrm{Fe}$ fertilized area in the Southern Ocean estimated with $\mathrm{Si}$ isotopic approaches, Biogeosciences, 11, 5827-5846, doi:10.5194/bg-115827-2014, 2014.

Cornet-Barthaux, V., Armand, L., and Quéguiner, B.: Biovolume and biomass estimates of key diatoms in the Southern Ocean, 
Aquat. Microb. Ecol., 48, 295-308, doi:10.3354/ame048295, 2007

Crawford, R.: The role of sex in the sedimentation of a marine diatom bloom, Limnol. Oceanogr., 40, 200-204, 1995.

Crosta, X., Pichon, J.-J., and Labracherie, M.: Distribution of Chaetoceros resting spores in modern peri-Antarctic sediments, Mar. Micropaleontol., 29, 283-299, doi:10.1016/S03778398(96)00033-3, 1997.

Davison, P. C., Checkley Jr., D. M., Koslow, J. A., and Barlow, J.: Carbon export mediated by mesopelagic fishes in the northeast Pacific Ocean, Prog. Oceanogr., 116, 14-30, doi:10.1016/j.pocean.2013.05.013, 2013.

DeMaster, D. J.: The supply and accumulation of silica in the marine environment, Geochim. Cosmochim. Ac., 45, 1715-1732, doi:10.1016/0016-7037(81)90006-5, 1981.

Doucette, G. J. and Fryxell, G. A.: Thalassiosira antarctica: vegetative and resting stage chemical composition of an ice-related marine diatom, Mar. Biol., 78, 1-6, doi:10.1007/BF00392964, 1983.

Dubischar, C. D. and Bathmann, U. V.: The occurrence of faecal material in relation to different pelagic systems in the Southern Ocean and its importance for vertical flux, Deep-Sea Res. Pt. II, 49, 3229-3242, doi:10.1016/S0967-0645(02)00080-2, 2002.

Dunbar, R. B.: Sediment trap experiments on the Antarctic continental margin., Antarct. J. US, 70-71, 1984.

Dutkiewicz, S., Follows, M. J., and Parekh, P.: Interactions of the iron and phosphorus cycles: A three-dimensional model study, Glob. Biogeochem. Cy., 19, GB1021, doi:10.1029/2004GB002342, 2005.

Ebersbach, F. and Trull, T. W.: Sinking particle properties from polyacrylamide gels during the KErguelen Ocean and Plateau compared Study (KEOPS): Zooplankton control of carbon export in an area of persistent natural iron inputs in the Southern Ocean, Limnol. Oceanogr., 53, 212-224, doi:10.4319/lo.2008.53.1.0212, 2008.

Ebersbach, F., Trull, T. W., Davies, D. M., and Bray, S. G.: Controls on mesopelagic particle fluxes in the Sub-Antarctic and Polar Frontal Zones in the Southern Ocean south of Australia in summer-Perspectives from free-drifting sediment traps, DeepSea Res. Pt. II, 58, 2260-2276, doi:10.1016/j.dsr2.2011.05.025, 2011.

Ebersbach, F., Assmy, P., Martin, P., Schulz, I., Wolzenburg, S., and Nöthig, E.-M.: Particle flux characterisation and sedimentation patterns of protistan plankton during the iron fertilisation experiment LOHAFEX in the Southern Ocean, Deep-Sea Res. Pt. I, 89, 94-103, doi:10.1016/j.dsr.2014.04.007, 2014.

Fischer, G., Fütterer, D., Gersonde, R., Honjo, S., Ostermann, D., and Wefer, G.: Seasonal variability of particle flux in the Weddell Sea and its relation to ice cover, Nature, 335, 426-428, doi:10.1038/335426a0, 1988 .

Fischer, G., Gersonde, R., and Wefer, G.: Organic carbon, biogenic silica and diatom fluxes in the marginal winter sea-ice zone and in the Polar Front Region: interannual variations and differences in composition, Deep-Sea Res. Pt. II, 49, 1721-=1745, doi:10.1016/S0967-0645(02)00009-7, 2002.

Fransz, H. G. and Gonzalez, S. R.: The production of Oithona similis (Copepoda: Cyclopoida) in the Southern Ocean, ICES, J. Mar. Sci. J. Cons., 52, 549-555, doi:10.1016/10543139(95)80069-7, 1995.
Garrison, D. L.: Monterey Bay Phytoplankton. II. Resting Spore Cycles in Coastal Diatom Populations, J. Plankton Res., 3, 137 156, doi:10.1093/plankt/3.1.137, 1981.

Gersonde, R. and Zielinski, U.: The reconstruction of late Quaternary Antarctic sea-ice distribution-the use of diatoms as a proxy for sea-ice, Palaeogeogr. Palaeoecl., 162, 263-286, doi:10.1016/S0031-0182(00)00131-0, 2000.

Gleiber, M. R., Steinberg, D. K., and Ducklow, H. W.: Time series of vertical flux of zooplankton fecal pellets on the continental shelf of the western Antarctic Peninsula, Mar. Ecol. Prog. Ser., 471, 23-36, doi:10.3354/meps10021, 2012.

Gomi, Y., Fukuchi, M., and Taniguchi, A.: Diatom assemblages at subsurface chlorophyll maximum layer in the eastern Indian sector of the Southern Ocean in summer, J. Plankton Res., 32, 1039 1050, doi:10.1093/plankt/fbq031, 2010.

Gonzalez, H. E. and Smetacek, V.: The possible role of the cyclopoid copepod Oithona in retarding vertical flux of zooplankton faecal material, Mar. Ecol.-Prog. Ser., 113, 233-246, 1994.

Grigorov, I., Rigual-Hernandez, A. S., Honjo, S., Kemp, A. E. S., and Armand, L. K.: Settling fluxes of diatoms to the interior of the Antarctic circumpolar current along $170^{\circ} \mathrm{W}$, Deep-Sea Res. Pt. I, 93, 1-13, doi:10.1016/j.dsr.2014.07.008, 2014.

Grimm, K. A., Lange, C. B., and Gill, A. S.: Biological forcing of hemipelagic sedimentary laminae; evidence from ODP Site 893, Santa Barbara Basin, California, J. Sediment. Res., 66, 613624, doi:10.1306/D42683C4-2B26-11D7-8648000102C1865D, 1996.

Hasle, G. R. and Syvertsen, E. E.: Chapter 2 - Marine Diatoms, in: Identifying Marine Phytoplankton, edited by: C. R. Tomas, 5-385, Academic Press, San Diego, 1997.

Hillebrand, H., Dürselen, C.-D., Kirschtel, D., Pollingher, U., and Zohary, T.: Biovolume Calculation for Pelagic and Benthic Microalgae, J. Phycol., 35, 403-424, doi:10.1046/j.15298817.1999.3520403.x, 1999.

Holm-Hansen, O., Kahru, M., Hewes, C. D., Kawaguchi, S., Kameda, T., Sushin, V. A., Krasovski, I., Priddle, J., Korb, R., Hewitt, R. P., and Mitchell, B. G.: Temporal and spatial distribution of chlorophyll-a in surface waters of the Scotia Sea as determined by both shipboard measurements and satellite data, DeepSea Res. Pt. II, 51, 1323-1331, doi:10.1016/j.dsr2.2004.06.004, 2004.

Holzer, M., Primeau, F. W., DeVries, T., and Matear, R.: The Southern Ocean silicon trap: Data-constrained estimates of regenerated silicic acid, trapping efficiencies, and global transport paths, J. Geophys. Res.-Oceans, 119, 313-331, doi:10.1002/2013JC009356, 2014.

Howard, A. G., Coxhead, A. J., Potter, I. A., and Watt, A. P.: Determination of dissolved aluminium by the micelle-enhanced fluorescence of its lumogallion complex, Analyst, 111, 1379-1382, doi:10.1039/AN9861101379, 1986.

Hutchins, D. A. and Bruland, K. W.: Iron-limited diatom growth and Si:N uptake ratios in a coastal upwelling regime, Nature, 393, 561-564, doi:10.1038/31203, 1998.

Ichinomiya, M., Gomi, Y., Nakamachi, M., Honda, M., Fukuchi, M., and Taniguchi, A.: Temporal variations in the abundance and sinking flux of diatoms under fast ice in summer near Syowa Station, East Antarctica, Polar Sci., 2, 33-40, doi:10.1016/j.polar.2008.01.001, 2008. 
Jackson, G. A. and Burd, A. B.: A model for the distribution of particle flux in the mid-water column controlled by subsurface biotic interactions, Deep-Sea Res. Pt. II, 49, 193-217, doi:10.1016/S0967-0645(01)00100-X, 2001.

Jackson, G. A., Waite, A. M., and Boyd, P. W.: Role of algal aggregation in vertical carbon export during SOIREE and in other low biomass environments, Geophys. Res. Lett., 32, L13607, doi:10.1029/2005GL023180, 2005.

Jin, X., Gruber, N., Dunne, J. P., Sarmiento, J. L., and Armstrong, R. A.: Diagnosing the contribution of phytoplankton functional groups to the production and export of particulate organic carbon, $\mathrm{CaCO}_{3}$, and opal from global nutrient and alkalinity distributions, Glob. Biogeochem. Cy., 20, GB2015, doi:10.1029/2005GB002532, 2006.

Jouandet, M.-P., Blain, S., Metzl, N., Brunet, C., Trull, T. W., and Obernosterer, I.: A seasonal carbon budget for a naturally iron-fertilized bloom over the Kerguelen Plateau in the Southern Ocean, Deep-Sea Res. Pt. II, 55, 856-867, doi:10.1016/j.dsr2.2007.12.037, 2008.

Jouandet, M.-P., Trull, T. W., Guidi, L., Picheral, M., Ebersbach, F., Stemmann, L., and Blain, S.: Optical imaging of mesopelagic particles indicates deep carbon flux beneath a natural ironfertilized bloom in the Southern Ocean, Limnol. Oceanogr., 56, 1130-1140, doi:10.4319/lo.2011.56.3.1130, 2011.

Jouandet, M.-P., Jackson, G. A., Carlotti, F., Picheral, M., Stemmann, L., and Blain, S.: Rapid formation of large aggregates during the spring bloom of Kerguelen Island: observations and model comparisons, Biogeosciences, 11, 4393-4406, doi:10.5194/bg-11-4393-2014, 2014.

Kato, M., Tanimura, Y., Matsuoka, K., and Fukusawa, H.: Planktonic diatoms from sediment traps in Omura Bay, western Japan with implications for ecological and taphonomic studies of coastal marine environments, Quat. Int., 105, 25-31, doi:10.1016/S1040-6182(02)00147-7, 2003.

Kemp, A. E. S. and Villareal, T. A.: High diatom production and export in stratified waters - A potential negative feedback to global warming, Prog. Oceanogr., 119, 4-23, doi:10.1016/j.pocean.2013.06.004, 2013.

Kemp, A. E. S., Pike, J., Pearce, R. B., and Lange, C. B.: The "Fall dump" - a new perspective on the role of a "shade flora" in the annual cycle of diatom production and export flux, Deep-Sea Res. Pt. II, 47, 2129-2154, doi:10.1016/S0967-0645(00)000199, 2000.

Kohfeld, K. E., Quéré, C. L., Harrison, S. P., and Anderson, R. F.: Role of Marine Biology in Glacial-Interglacial $\mathrm{CO}_{2}$ Cycles, Science, 308, 74-78, doi:10.1126/science.1105375, 2005.

Kopczynska, E. E., Dehairs, F., Elskens, M., and Wright, S.: Phytoplankton and microzooplankton variability between the Subtropical and Polar Fronts south of Australia: Thriving under regenerative and new production in late summer, J. Geophys. Res.Oceans, 106, 31597-31609, doi:10.1029/2000JC000278, 2001.

Kuwata, A. and Tsuda, A.: Selection and viability after ingestion of vegetative cells, resting spores and resting cells of the marine diatom, Chaetoceros pseudocurvisetus, by two copepods, J. Exp. Mar. Biol. Ecol., 322, 143-151, doi:10.1016/j.jembe.2005.02.013, 2005.

Kuwata, A., Hama, T., and Takahashi, M.: Ecophysiological characterization of two life forms, resting spores and resting cells, of a marine planktonic diatom, Mar. Ecol. Prog. Ser., 102, 245-255, 1993.

Lampitt, R. S., Noji, T., and Bodungen, B. von: What happens to zooplankton faecal pellets? Implications for material flux, Mar. Biol., 104, 15-23, doi:10.1007/BF01313152, 1990.

Lampitt, R. S., Boorman, B., Brown, L., Lucas, M., Salter, I., Sanders, R., Saw, K., Seeyave, S., Thomalla, S. J., and Turnewitsch, R.: Particle export from the euphotic zone: Estimates using a novel drifting sediment trap, 234Th and new production, Deep-Sea Res. Pt. I, 55, 1484-1502, doi:10.1016/j.dsr.2008.07.002, 2008.

Lampitt, R. S., Salter, I., and Johns, D.: Radiolaria: Major exporters of organic carbon to the deep ocean, Glob. Biogeochem. Cy., 23, GB1010, doi::10.1029/2008GB003221, 2009.

Lam, P. J. and Bishop, J. K. B.: High biomass, low export regimes in the Southern Ocean, Deep-Sea Res. Pt. II, 54, 601-638, doi:10.1016/j.dsr2.2007.01.013, 2007.

Lam, P. J., Doney, S. C., and Bishop, J. K. B.: The dynamic ocean biological pump: Insights from a global compilation of particulate organic carbon, $\mathrm{CaCO} 3$, and opal concentration profiles from the mesopelagic, Glob. Biogeochem. Cy., 25, GB3009, doi:10.1029/2010GB003868, 2011.

Lange, C. B., Weinheimer, A. L., Reid, F. M. H,. and Thunell, R. C.: Sedimentation patterns of diatoms, radiolarians, and silicoflagellates in Santa Barbara Basin, California, Calif. Coop. Ocean. Fish. Investig. Rep., 38, 161-170, 1997.

Lasbleiz, M., Leblanc, K., Blain, S., Ras, J., Cornet-Barthaux, V., Hélias Nunige, S., and Quéguiner, B.: Pigments, elemental composition $(\mathrm{C}, \mathrm{N}, \mathrm{P}$, and $\mathrm{Si})$, and stoichiometry of particulate matter in the naturally iron fertilized region of Kerguelen in the Southern Ocean, Biogeosciences, 11, 5931-5955, doi:10.5194/bg-115931-2014, 2014.

Laurenceau-Cornec, E. C., Trull, T. W., Davies, D. M., Bray, S. G., Doran, J., Planchon, F., Carlotti, F., Jouandet, M.-P., Cavagna, A.-J., Waite, A. M., and Blain, S.: The relative importance of phytoplankton aggregates and zooplankton fecal pellets to carbon export: insights from free-drifting sediment trap deployments in naturally iron-fertilised waters near the Kerguelen Plateau, Biogeosciences, 12, 1007-1027, doi:10.5194/bg-121007-2015, 2015.

Legendre, P. and Legendre, F. J. L.: Numerical Ecology, Édition : 2., Elsevier Science, Amsterdam, New York, 1998.

Leventer, A.: Sediment trap diatom assemblages from the northern Antarctic Peninsula region, Deep-Sea Res. Pt. I, 38, 1127-1143, doi:10.1016/0198-0149(91)90099-2, 1991.

Leventer, A. and Dunbar, R. B.: Diatom flux in McMurdo Sound, Antarctica, Mar. Micropaleontol., 12, 49-64, doi:10.1016/03778398(87)90013-2, 1987.

Lopes, C., Mix, A. C., and Abrantes, F.: Diatoms in northeast Pacific surface sediments as paleoceanographic proxies, Mar. Micropaleontol., 60, 45-65, doi:10.1016/j.marmicro.2006.02.010, 2006.

Madin, L. P.: Production, composition and sedimentation of salp fecal pellets in oceanic waters, Mar. Biol., 67, 39-45, doi:10.1007/BF00397092, 1982.

Maiti, K., Charette, M. A., Buesseler, K. O., and Kahru, M.: An inverse relationship between production and export efficiency in the Southern Ocean, Geophys. Res. Lett., 40, 1557-1561, doi:10.1002/grl.50219, 2013. 
Martin, J. H., Gordon, R. M., and Fitzwater, S. E.: Iron in Antarctic waters, Nature, 345, 156-158, doi:10.1038/345156a0, 1990.

Matsumoto, K., Sarmiento, J. L., and Brzezinski, M. A.: Silicic acid leakage from the Southern Ocean: A possible explanation for glacial atmospheric $p \mathrm{CO}_{2}$, Glob. Biogeochem. Cy., 16, 5-1, doi:10.1029/2001GB001442, 2002.

McQuoid, M. R. and Hobson, L. A.: Diatom Resting Stages, J. Phycol., 32, 889-902, doi:10.1111/j.0022-3646.1996.00889.x, 1996.

Menden-Deuer, S. and Lessard, E. J.: Carbon to volume relationships for dinoflagellates, diatoms, and other protist plankton, Limnol. Oceanogr., 45, 569-579, doi:10.4319/lo.2000.45.3.0569, 2000.

Moore, C. M., Mills, M. M., Arrigo, K. R., Berman-Frank, I., Bopp, L., Boyd, P. W., Galbraith, E. D., Geider, R. J., Guieu, C., Jaccard, S. L., Jickells, T. D., La Roche, J., Lenton, T. M., Mahowald, N. M., Marañón, E., Marinov, I., Moore, J. K., Nakatsuka, T., Oschlies, A., Saito, M. A., Thingstad, T. F., Tsuda, A., and Ulloa, O.: Processes and patterns of oceanic nutrient limitation, Nat. Geosci., 6, 701-710, doi:10.1038/ngeo1765, 2013.

Moore, J. K., Doney, S. C., Glover, D. M., and Fung, I. Y.: Iron cycling and nutrient-limitation patterns in surface waters of the World Ocean, Deep-Sea Res., 49, 463-507, doi:10.1016/S09670645(01)00109-6, 2001.

Mortlock, R. A. and Froelich, P. N.: A simple method for the rapid determination of biogenic opal in pelagic marine sediments, Deep-Sea Res. Pt. I, 36, 1415-1426, doi:10.1016/01980149(89)90092-7, 1989.

Mosseri, J., Quéguiner, B., Armand, L., and Cornet-Barthaux, V.: Impact of iron on silicon utilization by diatoms in the Southern Ocean: A case study of $\mathrm{Si} / \mathrm{N}$ cycle decoupling in a naturally iron-enriched area, Deep-Sea Res. Pt. II, 55, 801-819, doi:10.1016/j.dsr2.2007.12.003, 2008.

Nelson, D. M., Tréguer, P., Brzezinski, M. A., Leynaert, A., and Quéguiner, B.: Production and dissolution of biogenic silica in the ocean: Revised global estimates, comparison with regional data and relationship to biogenic sedimentation, Glob. Biogeochem. Cy., 9, 359-372, doi:10.1029/95GB01070, 1995.

Nelson, D. M., Brzezinski, M. A., Sigmon, D. E., and Franck, V. M.: A seasonal progression of Si limitation in the Pacific sector of the Southern Ocean, Deep-Sea Res. Pt. II, 48, 3973-3995, doi:10.1016/S0967-0645(01)00076-5, 2001.

Oku, O. and Kamatani, A.: Resting spore formation of the marine planktonic diatom Chaetoceros anastomosans induced by high salinity and nitrogen depletion, Mar. Biol., 127, 515-520, doi:10.1007/s002270050040, 1997.

Onodera, J., Watanabe, E., Harada, N., and Honda, M. C.: Diatom flux reflects water-mass conditions on the southern Northwind Abyssal Plain, Arctic Ocean, Biogeosciences, 12, 1373-1385, doi:10.5194/bg-12-1373-2015, 2015.

Park, J., Oh, I.-S., Kim, H.-C., and Yoo, S.: Variability of SeaWiFs chlorophyll-a in the southwest Atlantic sector of the Southern Ocean: Strong topographic effects and weak seasonality, DeepSea Res. Pt. I, 57, 604-620, doi:10.1016/j.dsr.2010.01.004, 2010.

Park, Y.-H., Roquet, F., Durand, I., and Fuda, J.-L.: Large-scale circulation over and around the Northern Kerguelen Plateau, DeepSea Res. Pt. II, 55, 566-581, doi:10.1016/j.dsr2.2007.12.030, 2008.

Park, Y.-H., Durand, I., Kestenare, E., Rougier, G., Zhou, M., d'Ovidio, F., Cotté, C., and Lee, J.-H.: Polar Front around the Kerguelen Islands: An up-to-date determination and associated circulation of surface/subsurface waters, J. Geophys. Res.Oceans, 119, 6575-6592, doi:10.1002/2014JC010061, 2014.

Parslow, J. S., Boyd, P. W., Rintoul, S. R., and Griffiths, F. B.: A persistent subsurface chlorophyll maximum in the Interpolar Frontal Zone south of Australia: Seasonal progression and implications for phytoplankton-light-nutrient interactions, J. Geophys. Res.Oceans, 106, 31543-31557, doi:10.1029/2000JC000322, 2001.

Pilskaln, C. H., Manganini, S. J., Trull, T. W., Armand, L., Howard, W., Asper, V. L., and Massom, R.: Geochemical particle fluxes in the Southern Indian Ocean seasonal ice zone: Prydz Bay region, East Antarctica, Deep-Sea Res. Pt. I, 51, 307-332, doi:10.1016/j.dsr.2003.10.010, 2004.

Pinkerton, M. H., Smith, A. N. H., Raymond, B., Hosie, G. W., Sharp, B., Leathwick, J. R., and Bradford-Grieve, J. M.: Spatial and seasonal distribution of adult Oithona similis in the Southern Ocean: Predictions using boosted regression trees, Deep-Sea Res. Pt. I, 57, 469-485, doi:10.1016/j.dsr.2009.12.010, 2010.

Pollard, R., Lucas, M., and Read, J.: Physical controls on biogeochemical zonation in the Southern Ocean, Deep-Sea Res. Pt. II, 49, 3289-3305, doi:10.1016/S0967-0645(02)00084-X, 2002.

Primeau, F. W., Holzer, M., and DeVries, T.: Southern Ocean nutrient trapping and the efficiency of the biological pump, J. Geophys. Res.-Oceans, 118, 2547-2564, doi:10.1002/jgrc.20181, 2013.

Quéguiner, B.: Iron fertilization and the structure of planktonic communities in high nutrient regions of the Southern Ocean, Deep-Sea Res. Pt. II, 90, 43-54, doi:10.1016/j.dsr2.2012.07.024, 2013.

Ragueneau, O., Savoye, N., Del Amo, Y., Cotten, J., Tardiveau, B., and Leynaert, A.: A new method for the measurement of biogenic silica in suspended matter of coastal waters: using Si:Al ratios to correct for the mineral interference, Cont. Shelf Res., 25, 697710, doi:10.1016/j.csr.2004.09.017, 2005.

Ragueneau, O., Schultes, S., Bidle, K., Claquin, P., and Moriceau, B.: Si and C interactions in the world ocean: Importance of ecological processes and implications for the role of diatoms in the biological pump, Glob. Biogeochem. Cy., 20, GB4S02, doi:10.1029/2006GB002688, 2006.

Rembauville, M., Salter, I., Leblond, N., Gueneugues, A., and Blain, S.: Export fluxes in a naturally iron-fertilized area of the Southern Ocean - Part 1: Seasonal dynamics of particulate organic carbon export from a moored sediment trap, Biogeosciences, 12, 3153-3170, doi:10.5194/bg-12-3153-2015, 2015.

Richardson, K., Visser, A. W., and Pedersen, F. B.: Subsurface phytoplankton blooms fuel pelagic production in the North Sea, J. Plankton Res., 22, 1663-1671, doi:10.1093/plankt/22.9.1663, 2000.

Rigual-Hernández, A. S., Trull, T. W., Bray, S. G., Closset, I.,fWe directly compared and Armand, L. K.: Seasonal dynamics in diatom and particulate export fluxes to the deep sea in the Australian sector of the southern Antarctic Zone, J. Mar. Syst., 142, 62-74, doi:10.1016/j.jmarsys.2014.10.002, 2015.

Romero, O. E. and Armand, L.: Marine diatoms as indicators of modern changes in oceanographic conditions. In: 2nd Edition The Diatoms: Applications for the Environmental and Earth Sciences, Camb. Univ. Press, 373-400, 2010.

Romero, O. E., Lange, C. B., Fisher, G., Treppke, U. F., and Wefer, G.: Variability in export prodution documented by downward 
fluxes and species composition of marine planktonic diatoms: observations from the tropical and equatorial Atlantic, in: The Use of Proxies in Paleoceanography, Examples from the South Atlantic, 365-392, Heidelberg, Berlin, 1999.

Romero, O. E., Fischer, G., Lange, C. B., and Wefer, G.: Siliceous phytoplankton of the western equatorial Atlantic: sediment traps and surface sediments, Deep-Sea Res. Pt. II, 47, 1939-1959, doi:10.1016/S0967-0645(00)00012-6, 2000.

Rynearson, T. A., Richardson, K., Lampitt, R. S., Sieracki, M. E., Poulton, A. J., Lyngsgaard, M. M., and Perry, M. J.: Major contribution of diatom resting spores to vertical flux in the sub-polar North Atlantic, Deep-Sea Res. Pt. I, 82, 60-71, doi:10.1016/j.dsr.2013.07.013, 2013.

Sackett, O., Armand, L., Beardall, J., Hill, R., Doblin, M., Connelly, C., Howes, J., Stuart, B., Ralph, P., and Heraud, P.: Taxonspecific responses of Southern Ocean diatoms to $\mathrm{Fe}$ enrichment revealed by synchrotron radiation FTIR microspectroscopy, Biogeosciences, 11, 5795-5808, doi:10.5194/bg-11-5795-2014, 2014.

Sallée, J.-B., Matear, R. J., Rintoul, S. R., and Lenton, A.: Localized subduction of anthropogenic carbon dioxide in the Southern Hemisphere oceans, Nat. Geosci., 5, 579-584, doi:10.1038/ngeo1523, 2012.

Salter, I., Lampitt, R. S., Sanders, R., Poulton, A., Kemp, A. E. S., Boorman, B., Saw, K., and Pearce, R.: Estimating carbon, silica and diatom export from a naturally fertilised phytoplankton bloom in the Southern Ocean using PELAGRA: A novel drifting sediment trap, Deep-Sea Res. Pt. II, 54, 2233-2259, doi:10.1016/j.dsr2.2007.06.008, 2007.

Salter, I., Kemp, A. E. S., Moore, C. M., Lampitt, R. S., Wolff, G. A., and Holtvoeth, J.: Diatom resting spore ecology drives enhanced carbon export from a naturally iron-fertilized bloom in the Southern Ocean, Glob. Biogeochem. Cy., 26, GB1014, doi:10.1029/2010GB003977, 2012.

Sancetta, C.: Diatoms in the Gulf of California: Seasonal flux patterns and the sediment record for the last 15000 years, Paleoceanography, 10, 67-84, doi:10.1029/94PA02796, 1995.

Sanders, J. G. and Cibik, S. J.: Reduction of growth rate and resting spore formation in a marine diatom exposed to low levels of cadmium, Mar. Environ. Res., 16, 165-180, doi:10.1016/01411136(85)90136-9, 1985.

Sarmiento, J. L., Gruber, N., Brzezinski, M. A., and Dunne, J. P.: High-latitude controls of thermocline nutrients and low latitude biological productivity, Nature, 427, 56-60, doi:10.1038/nature02127, 2004.

Schnack-Schiel, S. B. and Isla, E.: The role of zooplankton in the pelagic-benthic coupling of the Southern Ocean, Sci. Mar., 69, 39-55, 2005.

Smetacek, V., Assmy, P., and Henjes, J.: The role of grazing in structuring Southern Ocean pelagic ecosystems and biogeochemical cycles, Antarct. Sci., 16, 541-558, doi:10.1017/S0954102004002317, 2004.

Smetacek, V. S.: Role of sinking in diatom life-history cycles: ecological, evolutionary and geological significance, Mar. Biol., 84, 239-251, doi:10.1007/BF00392493, 1985.

Steinberg, D. K., Goldthwait, S. A., and Hansell, D. A.: Zooplankton vertical migration and the active transport of dissolved organic and inorganic nitrogen in the Sargasso Sea, Deep-Sea
Res. Pt. I, 49, 1445-1461, doi:10.1016/S0967-0637(02)00037-7, 2002.

Suzuki, H., Sasaki, H., and Fukuchi, M.: Short-term variability in the flux of rapidly sinking particles in the Antarctic marginal ice zone, Polar Biol., 24, 697-705, doi:10.1007/s003000100271, 2001.

Suzuki, H., Sasaki, H., and Fukuchi, M.: Loss Processes of Sinking Fecal Pellets of Zooplankton in the Mesopelagic Layers of the Antarctic Marginal Ice Zone, J. Oceanogr., 59, 809-818, doi:10.1023/B:JOCE.0000009572.08048.0d, 2003.

Takahashi, T., Sweeney, C., Hales, B., Chipman, D., Newberger, T., Goddard, J., Iannuzzi, R., and Sutherland, S.: The Changing Carbon Cycle in the Southern Ocean, Oceanography, 25, 26-37, doi:10.5670/oceanog.2012.71, 2012.

Takeda, S.: Influence of iron availability on nutrient consumption ratio of diatoms in oceanic waters, Nature, 393, 774-777, doi:10.1038/31674, 1998.

Tarling, G. A., Ward, P., Atkinson, A., Collins, M. A., and Murphy, E. J.: DISCOVERY 2010: Spatial and temporal variability in a dynamic polar ecosystem, Deep-Sea Res. Pt. II, 59-60, 1-13, doi:10.1016/j.dsr2.2011.10.001, 2012.

Taylor, S. R., and McClennan, S. M.: The continental crust: Its composition and evolution, Geol. J., 21, 85-86, doi:10.1002/gj.3350210116, 1986.

Thomalla, S. J., Fauchereau, N., Swart, S., and Monteiro, P. M. S.: Regional scale characteristics of the seasonal cycle of chlorophyll in the Southern Ocean, Biogeosciences, 8, 2849-2866, doi:10.5194/bg-8-2849-2011, 2011.

Treppke, U. F., Lange, C. B., and Wefer, G.: Vertical fluxes of diatoms and silicoflagellates in the eastern equatorial Atlantic, and their contribution to the sedimentary record, Mar. Micropaleontol., 28, 73-96, doi:10.1016/0377-8398(95)00046-1, 1996.

Trull, T. W., Davies, D. M., Dehairs, F., Cavagna, A.-J., Lasbleiz, M., Laurenceau-Cornec, E. C., d'Ovidio, F., Planchon, F., Leblanc, K., Quéguiner, B., and Blain, S.: Chemometric perspectives on plankton community responses to natural iron fertilisation over and downstream of the Kerguelen Plateau in the Southern Ocean, Biogeosciences, 12, 1029-1056, doi:10.5194/bg-121029-2015, 2015.

Uitz, J., Claustre, H., Griffiths, F. B., Ras, J., Garcia, N., and Sandroni, V.: A phytoplankton class-specific primary production model applied to the Kerguelen Islands region (Southern Ocean), Deep-Sea Res. Pt. I, 56, 541-560, doi:10.1016/j.dsr.2008.11.006, 2009.

Venables, H. and Moore, C. M.: Phytoplankton and light limitation in the Southern Ocean: Learning from high-nutrient, high-chlorophyll areas, J. Geophys. Res.-Oceans, 115, C02015, doi:10.1029/2009JC005361, 2010.

Von Bodungen, B.: Phytoplankton growth and krill grazing during spring in the Bransfield Strait, Antarctica - Implications from sediment trap collections, Polar Biol., 6, 153-160, doi:10.1007/BF00274878, 1986.

Von Bodungen, B., Fischer, G., Nöthig, E.-M., and Wefer, G.: Sedimentation of krill faeces during spring development of phytoplankton in Bransfield Strait, Antarctica, Mitt Geol Paläont Inst Univ Hambg. SCOPE/UNEP Sonderbd, 62, 243-257, 1987.

Weber, T. S. and Deutsch, C.: Ocean nutrient ratios governed by plankton biogeography, Nature, 467, 550-554, doi:10.1038/nature09403, 2010. 
Wefer, G. and Fischer, G.: Annual primary production and export flux in the Southern Ocean from sediment trap data, Mar. Chem., 35, 597-613, doi:10.1016/S0304-4203(09)90045-7, 1991.

Wefer, G., Fischer, G., Füetterer, D., and Gersonde, R.: Seasonal particle flux in the Bransfield Strait, Antartica, Deep-Sea Res. Pt. I, 35, 891-898, doi:10.1016/0198-0149(88)90066-0, 1988.

Wefer, G. G., Fisher, D. K., Futterer, R., Gersonde, R., Honjo, S., and Ostermann, D.: Particle sedimentation and productivity in Antarctic waters of the Atlantic sector, in: Geological history of the polar oceans?, Arctic versus Antarctic, 363-379, Kluwer Academic Publishers, The Netherlands, 1990.

Westberry, T. K., Behrenfeld, M. J., Milligan, A. J., and Doney, S. C.: Retrospective satellite ocean color analysis of purposeful and natural ocean iron fertilization, Deep-Sea Res. Pt. I, 73, 1-16, doi:10.1016/j.dsr.2012.11.010, 2013.

Wilson, S. E., Steinberg, D. K., and Buesseler, K. O.: Changes in fecal pellet characteristics with depth as indicators of zooplankton repackaging of particles in the mesopelagic zone of the subtropical and subarctic North Pacific Ocean, Deep-Sea Res. Pt. II, 55, 1636-1647, doi:10.1016/j.dsr2.2008.04.019, 2008.
Wilson, S., E., Ruhl, H. A., and Smith Jr, K. L.: Zooplankton fecal pellet flux in the abyssal northeast Pacific: A 15 year time-series study, Limnol. Oceanogr., 58, 881-892, doi:10.4319/lo.2013.58.3.0881, 2013.

Wolff, E. W., Fischer, H., Fundel, F., Ruth, U., Twarloh, B., Littot, G. C., Mulvaney, R., Röthlisberger, R., de Angelis, M., Boutron, C. F., Hansson, M., Jonsell, U., Hutterli, M. A., Lambert, F., Kaufmann, P., Stauffer, B., Stocker, T. F., Steffensen, J. P., Bigler, M., Siggaard-Andersen, M. L., Udisti, R., Becagli, S., Castellano, E., Severi, M., Wagenbach, D., Barbante, C., Gabrielli, P., and Gaspari, V.: Southern Ocean sea-ice extent, productivity and iron flux over the past eight glacial cycles, Nature, 440, 491-496, doi:10.1038/nature04614, 2006.

Yoon, W., Kim, S., and Han, K.: Morphology and sinking velocities of fecal pellets of copepod, molluscan, euphausiid, and salp taxa in the northeastern tropical Atlantic, Mar. Biol., 139, 923-928, doi:10.1007/s002270100630, 2001.

Zielinski, U. and Gersonde, R.: Diatom distribution in Southern Ocean surface sediments (Atlantic sector): Implications for paleoenvironmental reconstructions, Palaeogeogr. Palaeoecl., 129, 213-250, doi:10.1016/S0031-0182(96)00130-7, 1997. 